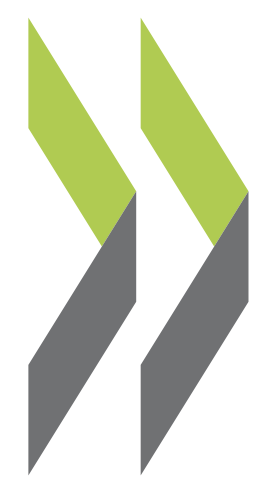

OECD Economics Department Working Papers No. 1156

Making the Banking Sector More Resilient and Reducing Household Debt in the Netherlands

Rafał Kierzenkowski, Olena Havrylchyk, Pierre Beynet 
Organisation de Coopération et de Développement Économiques

Organisation for Economic Co-operation and Development

28-Aug-2014

ECONOMICS DEPARTMENT

English - Or. English

\section{MAKING THE BANKING SECTOR MORE RESILIENT AND REDUCING HOUSEHOLD DEBT IN THE NETHERLANDS}

\section{ECONOMICS DEPARTMENT WORKING PAPERS No. 1156}

By Rafał Kierzenkowski, Olena Havrylchyk and Pierre Beynet

OECD Working Papers should not be reported as representing the official views of the OECD or of its member countries. The opinions expressed and arguments employed are those of the author(s).

Authorised for publication by Alvaro Pereira, Director, Country Studies Branch, Economics Department.

All Economics Department Working Papers are available through OECD's internet website at http://www.oecd.org/eco/workingpapers

Complete document available on OLIS in its original format

This document and any map included herein are without prejudice to the status of or sovereignty over any territory, to the delimitation of international frontiers and boundaries and to the name of any territory, city or area. 
OECD Working Papers should not be reported as representing the official views of the OECD or of its member countries. The opinions expressed and arguments employed are those of the author(s).

Working Papers describe preliminary results or research in progress by the author(s) and are published to stimulate discussion on a broad range of issues on which the OECD works.

Comments on Working Papers are welcomed, and may be sent to the Economics Department, OECD, 2 rue André-Pascal, 75775 Paris Cedex 16, France, or by e-mail to eco.contact@oecd.org.

This document and any map included herein are without prejudice to the status of or sovereignty over any territory, to the delimitation of international frontiers and boundaries and to the name of any territory, city or area.

The statistical data for Israel are supplied by and under the responsibility of the relevant Israeli authorities. The use of such data by the OECD is without prejudice to the status of the Golan Heights, East Jerusalem and Israeli settlements in the West Bank under the terms of international law.

\section{(C) OECD (2014)}

You can copy, download or print OECD content for your own use, and you can include excerpts from OECD publications, databases and multimedia products in your own documents, presentations, blogs, websites and teaching materials, provided that suitable acknowledgment of OECD as source and copyright owner is given. All requests for commercial use and translation rights should be submitted to rights@oecd.org 
ECO/WKP(2014)52

\section{ABSTRACT/RÉSUMÉ}

\section{Making the Banking Sector More Resilient and Reducing Household Debt in the Netherlands}

Dutch banks were put under heavy strains early in the global downturn and have comparatively weak financial buffers to cope with new shocks. Falling house prices have increased the share of households with negative home equity to nearly $35 \%$ for home-owning households and $40 \%$ for mortgage holders. Even though defaults have so far been limited, mortgage amortisation is low and risks are concentrated among younger borrowers who often do not have sufficient resources to cope with adverse shocks. Banks are very large relative to the size of the domestic economy, have sizeable cross-border exposures and rely significantly on wholesale funding. Resolution procedures should be strengthened to reduce the potential cost for the taxpayer and the regulator's tools available to reduce risks should be expanded. In particular, banks should set aside sufficient provisions for expected losses and problem loans, which requires some harmonisation of the definition of non-performing loans across banks. Higher capital buffers would bolster financial stability and help ensure access to market funding while lowering its cost. Welcome measures have been taken to encourage household deleveraging, but deeper and broader steps are needed to bolster financial stability and improve consumer protection when the housing market starts to recover durably and over the medium term. The stock of existing mortgages should be gradually converted into amortising mortgages, the cap on the loanto-value ratio reduced significantly below $100 \%$ and housing subsidies to homeownership cut more decisively.

This Working Paper relates to the 2014 OECD Economic Survey of the Netherlands (www.oecd.org/eco/surveys/economic-survey-netherlands.htm).

JEL classification: G21, G28, D14, D18

Keywords: Banks, households, mortgages, amortisation, capital, house prices, deleveraging, non-performing loans, financial stability, Netherlands.

\section{Renforcer la capacité de résistance du secteur bancaire et réduire la dette des ménages aux Pays-Bas}

Les banques néerlandaises ont été mises à rude épreuve au début de la récession mondiale et sont dotées de réserves financières relativement modestes pour faire face à de nouveaux chocs. La baisse des prix immobiliers a fait augmenter la proportion de ménages ayant un patrimoine en logements négatif, qui s'établissait à près de $35 \%$ pour les ménages propriétaires de leur habitation et $40 \%$ pour les titulaires d'un emprunt hypothécaire. Même si les défauts de paiement ont été limités jusqu'ici, l'amortissement des prêts hypothécaires est faible et les risques sont concentrés dans la catégorie des emprunteurs les plus jeunes, qui n'ont souvent pas des ressources suffisantes pour absorber des chocs négatifs. Les banques sont de très grande taille au regard de celle de l'économie néerlandaise, sont très exposées à des risques extérieurs et sont fortement tributaires des financements de marché. Il faudrait renforcer les procédures de résolution des défaillances bancaires afin de réduire leur coût potentiel pour les contribuables, et la palette d'instruments dont dispose l'autorité de régulation pour réduire les risques devrait être élargie. Il conviendrait en particulier que les banques constituent des provisions suffisantes au regard des pertes attendues et des prêts à problème, ce qui passe par une harmonisation de la définition des créances improductives entre les banques. Une augmentation des volants de fonds propres renforcerait la stabilité financière et contribuerait à garantir l'accès aux financements de marché tout en réduisant leur coût. Des mesures bienvenues ont été prises pour encourager les ménages à se désendetter, mais des initiatives plus ambitieuses et de portée plus générale seront nécessaires pour renforcer la stabilité financière et améliorer la protection des consommateurs dès que le marché du logement sera entré dans une phase de redressement durable et à moyen terme. Il faudrait que l'encours de crédits hypothécaires soit converti progressivement en prêts à amortissement régulier, que la quotité de financement maximale soit abaissée à un taux nettement inférieur à $100 \%$, et que les aides au logement dont bénéficient les propriétaires occupants soient réduites de manière plus décisive.

Ce Document de travail se rapporte à l'Étude économique de l'OCDE des Pays Bas, 2014 (www.oecd.org/fr/eco/etudes/pays-bas.htm).

Classification JEL : G21, G28, D14, D18

Mots clefs: Banques, ménages, prêts hypothécaires, amortissement, fonds propres, désendettement, créances improductifs, stabilité financière, Pays-Bas. 


\section{TABLE OF CONTENTS}

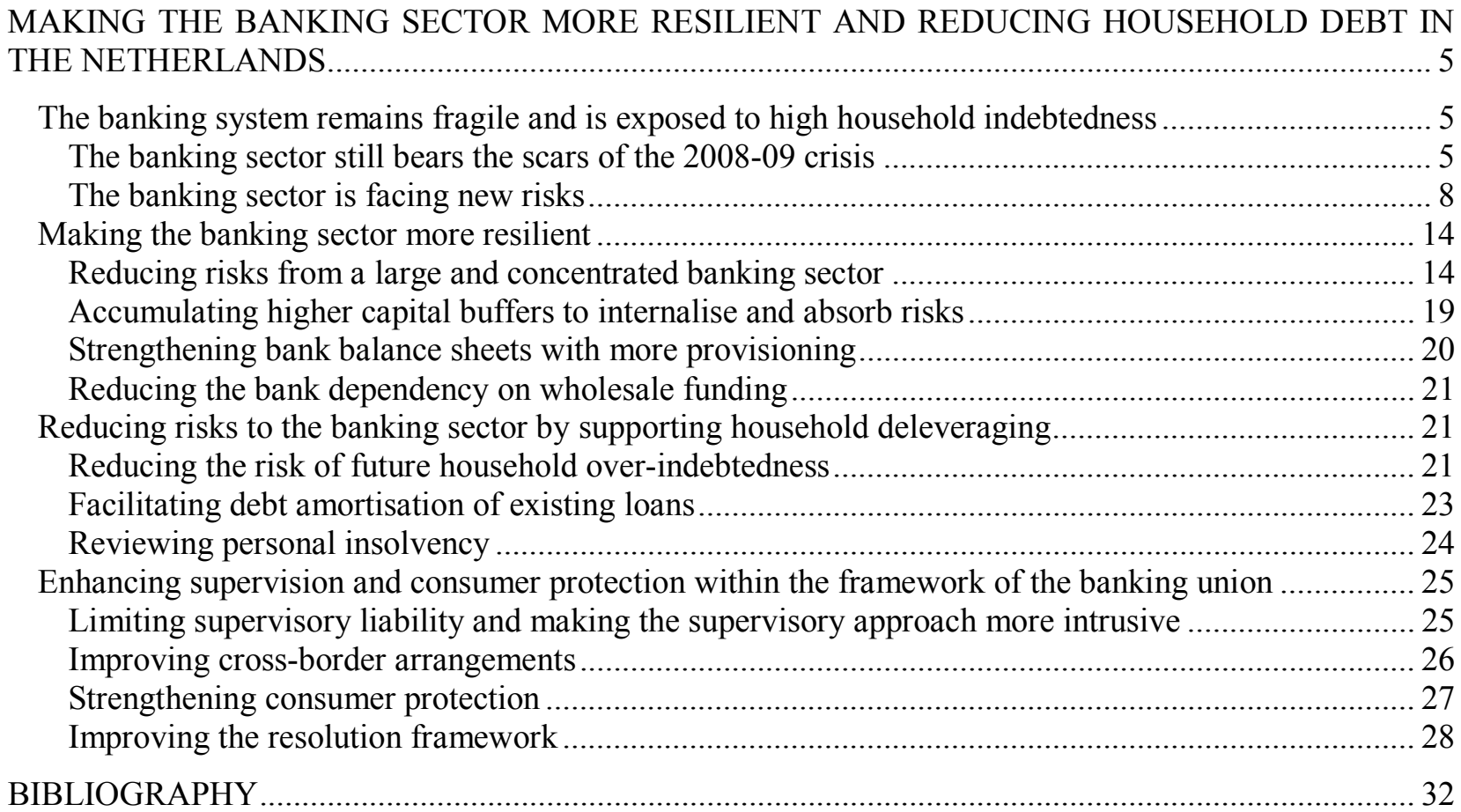

\section{Boxes}

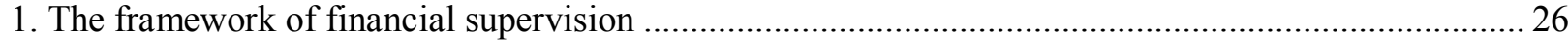

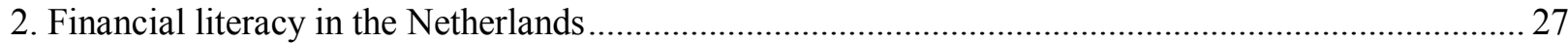

3. Main policy recommendations to increase the resilience of the banking sector ................................. 30

\section{Figures}

1. Risk premiums on market funding have become more costly and volatile....................................... 6

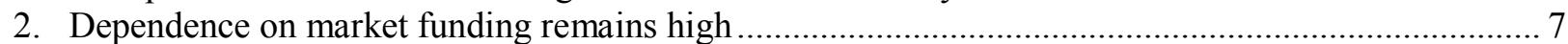

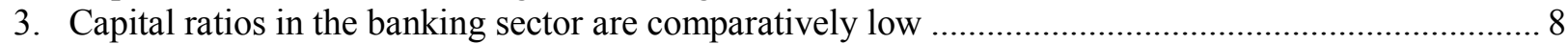

4. Financial buffers to absorb losses from non-performing loans are relatively weak ............................. 8

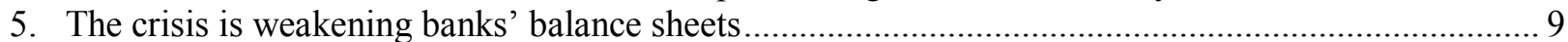

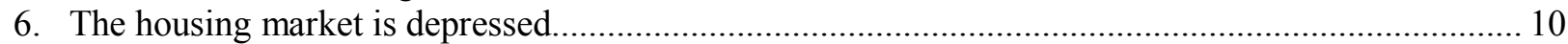

7. House prices in relation to incomes and rents across the OECD .................................................. 10

8. Market share of mortgages with deferred amortisation has expanded sharply .................................. 11

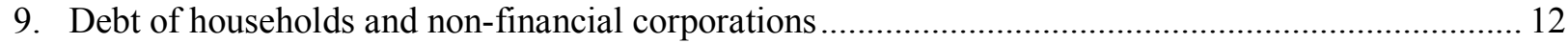

10. Household balance sheets have become more stretched ................................................................. 13

11. Risks are concentrated among young and prime-age households ................................................ 14

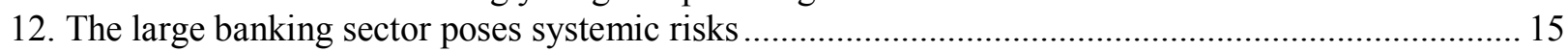

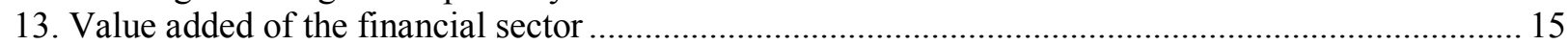

14. Foreign claims of banks are large but have been reduced by half................................................. 16

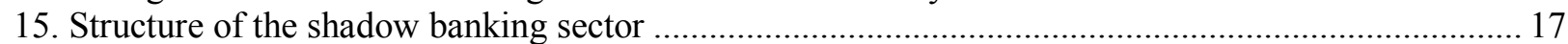

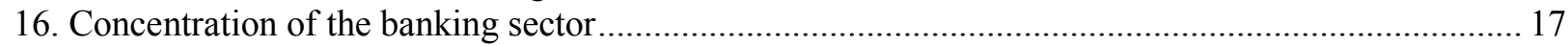

17. The allocation of lending has been skewed towards households .................................................... 18

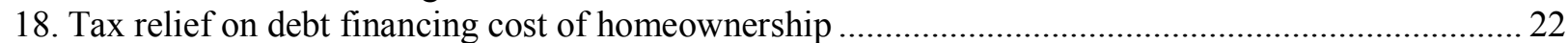

19. Feedback effects between house prices and household debt are strong ........................................... 22

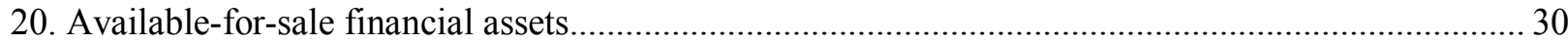


ECO/WKP(2014)52

\title{
MAKING THE BANKING SECTOR MORE RESILIENT AND REDUCING HOUSEHOLD DEBT IN THE NETHERLANDS
}

\author{
By Rafał Kierzenkowski, Olena Havrylchyk and Pierre Beynet ${ }^{1}$
}

The financial sector is facing a second difficult period since the start of the Great Recession in 2008. In the aftermath of the financial crisis, several financial institutions incurred major difficulties (OECD, 2010). In the banking sector, liquidity dried up and some banks were excessively leveraged or overly exposed to US subprime mortgages and financial instruments derived therefrom. ABN AMRO had to be nationalised in late 2008 following a failed takeover by Royal Bank of Scotland, Santander and Fortis. The solvency of pension funds was also put under pressure by financial market developments, as assessed in a chapter on the vulnerability of the pension system to financial crises of the 2010 Survey (OECD, 2010; Høj, 2011a). In both sectors, urgent measures were taken to circumvent the crisis which originated from a brutal, temporary and well identified shock.

Current challenges for banks arise from a more traditional and larger set of assets, i.e. loans to households and firms, and are potentially more long lasting. With the Netherlands being in recession or witnessing weak growth for five years and house prices regularly falling, highly indebted households see their net wealth progressively eroded, which pushes them to reduce their consumption and housing investment. This in turn undermines growth and house prices further, creating a negative spiral. Such a situation impacts banks in return as rising non-performing loans and a lower valuation of banks' collateral increase their exposure to the risks of default, which then leads them to restrict lending. Credit conditions are further tightened by poor growth prospects. In addition, the specific feature of the mortgage lending market in the Netherlands is creating a sizeable medium-term solvability risk when a significant number of loans whose amortisation has been deferred for many years will fall due. In the meantime, those mortgages have to be financed mainly through a heavy dependence on wholesale markets, which creates liquidity risks for banks.

After assessing the challenges arising from a large banking sector and the linkages between households' and banks' simultaneous deleveraging, this paper analyses how to make the banking sector more resilient and encourage household debt reduction.

\section{The banking system remains fragile and is exposed to high household indebtedness}

\section{The banking sector still bears the scars of the 2008-09 crisis}

Banks continue to rely on state support

The Dutch financial sector was severely affected by the 2008-09 crisis. As a consequence, government intervention during the early stage of the crisis was substantial (OECD, 2010), involving

1. Rafał Kierzenkowski is a Senior Economist and Head of the Netherlands/United Kingdom desk in the Country Studies Branch of the Economics Department of the OECD, contact email: rafal.kierzenkowski@,oecd.org. Olena Havrylchyk is Assistant Professor at Paris Nanterre University and was external consultant to the OECD when this work was done. Pierre Beynet is Head of Division at the OECD. This paper was prepared for the OECD Economic Survey of the Netherlands published in April 2014 under the authority of the Economic and Development Review Committee. The authors would like to thank Andrew Dean, Robert Ford and Dutch government officials for their valuable comments and suggestions. Special thanks are due to Gabor Fulop for statistical assistance and Dacil Kurzweg for technical preparation. 
equity injections with voting and non-voting rights (EUR 20 billion or 3.5\% of GDP) and liquidity measures and guarantees (EUR 200 billion or $35 \%$ of GDP). As of today, the government still holds a substantial stake in most banks. The government owns EUR 2.25 billion of non-voting core capital securities at ING, ABN AMRO is 98\%-controlled by the government and SNS Reaal was liable for EUR 850 million of public capital received in 2008, at the time of its nationalisation on 1 February 2013.

Government support is being gradually reduced, as disposal of impaired assets, restructuring and divestment are ongoing. Several financial institutions have repaid capital injections to the government through capital issuance and the sale of foreign operations. The bailout of the financial sector had increased gross public debt by around $15 \%$ of gross domestic product (GDP), but two-thirds of the costs have been recovered (IMF, 2013a). Contingent liabilities linked to the financial sector are expected to be scaled down to approximately 30\% of GDP in 2014 (Ministry of Finance, 2013a). The government is developing a timetable that will determine its gradual exit from banks' ownership which would be a step in the right direction. ABN AMRO is planned to be privatised in 2015.

\section{Banks' reliance on wholesale funding is still high}

Dutch banks continue to depend heavily on international capital markets to fund their assets. Risk-free interest rates have dropped, but risk premiums facing banks have increased and have become more volatile (Figure 1). Credit default swap spreads on senior debt do not seem high in international comparison, but the exposure of Dutch banks to refinancing risks is large as they combine among the highest loan-todeposit ratios and levels of external bank debt in the OECD (Figure 2). In particular, short-term external liabilities of Dutch banks are about 45\% of GDP. Moreover, Dutch banks also face growing regulatory barriers to attract foreign deposits (Jansen et al., 2013).

Figure 1. Risk premiums on market funding have become more costly and volatile Credit default swap (CDS) spreads of banking sectors, basis points ${ }^{1}$
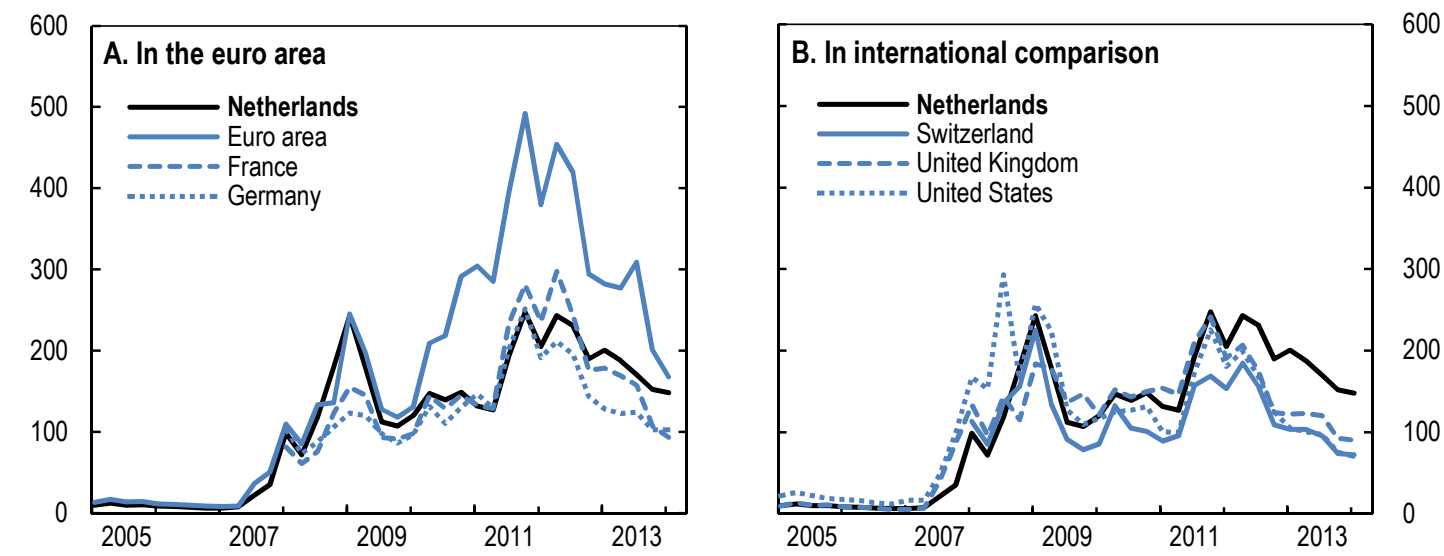

1. Five-year senior debt, mid-rate spreads between the entity and the relevant benchmark curve. Quarterly data calculated as the unweighted average of end-of-month figures. Figures for the Netherlands are calculated as the unweighted average of CDS spreads of four banks: SNS Bank, ING Bank, Rabobank and ABN AMRO.

Source: Datastream. 
Figure 2. Dependence on market funding remains high
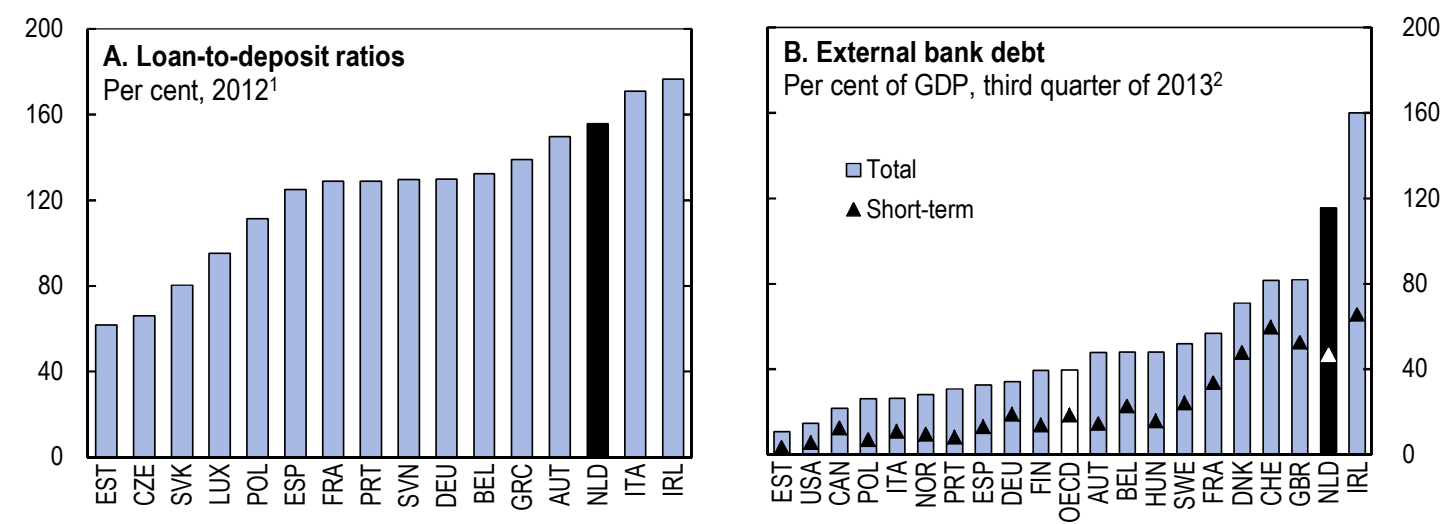

1. Ratio of loans and receivables including finance leases to total deposits other than from credit institutions. Data refer to domestic banking groups and stand-alone banks.

2. Total international debt liabilities and international debt liabilities with residual maturity below one year towards BIS reporting banks. The OECD aggregate excludes Luxembourg.

Source: ECB (2014), "Consolidated Banking Data", Statistical Data Warehouse, European Central Bank, March and BIS (2014), "Consolidated Banking Statistics", BIS Statistics, Bank for International Settlements, March.

\section{Prudential ratios are not that strong}

Progress has been made to strengthen bank capital since the outset of the crisis. Yet, international comparison can currently only be made on the Basel II basis and regulatory ratios of total and Tier 1 capital to risk-weighted assets are not comparatively strong on this account (Figure 3, Panel A). Also, unweighted measures of capital ratios (or leverage ratios) are lower than in many other countries (Figure 3, Panel B). According to the central bank (De Nederlandsche Bank, DNB), Dutch banks are making significant progress in the implementation of Basel III standards, which will be gradually introduced between 2014 and 2019. Based on end-state definition to be fully applicable in 2019, core Tier 1 ratio was at $11.5 \%$ in the Netherlands in the second half of 2012 and the leverage ratio was around $3.5 \%$ (DNB, 2013a). Yet, the Dutch banking sector still has a long way to go to meet all capital requirements, including over 2\% of GDP of net additional capital (DNB, 2014). Beyond asset composition driving a wedge between risk-adjusted and unadjusted capital positions, there is evidence of cross-country and cross-bank heterogeneity in banks' average risk weights driven by bank and supervisory practices (BIS, 2013a).

The level of non-performing loans (NPLs) is not very high (Figure 4, Panel A). Yet the amount of provisions made relative to the value of non-performing loans and bank capital is relatively low. Provisions are such that banks' capital would be cut by half to absorb losses in case all NPLs were fully written off in the worst case scenario and notwithstanding the value of banks' collateral (Figure 4, Panel B). This is an indication of a rather low capacity of banks to withstand losses from NPLs. Coverage ratios, measuring loan loss provisions as a percentage of NPLs, have been flat at around $35 \%$ and are ten percentage points lower than the median of ratios in the euro area (ECB, 2013a). Moreover, a low incidence of loans in arrears could be underestimated, notably because there is no uniform definition of NPLs. A lack of harmonised definition is also a broader issue in the euro area which is being addressed by the European Banking Authority so as a new definition of NPLs is used in the asset quality review of the European Central Bank (ECB). 
Figure 3. Capital ratios in the banking sector are comparatively low Per cent, third quarter of $2013^{1}$
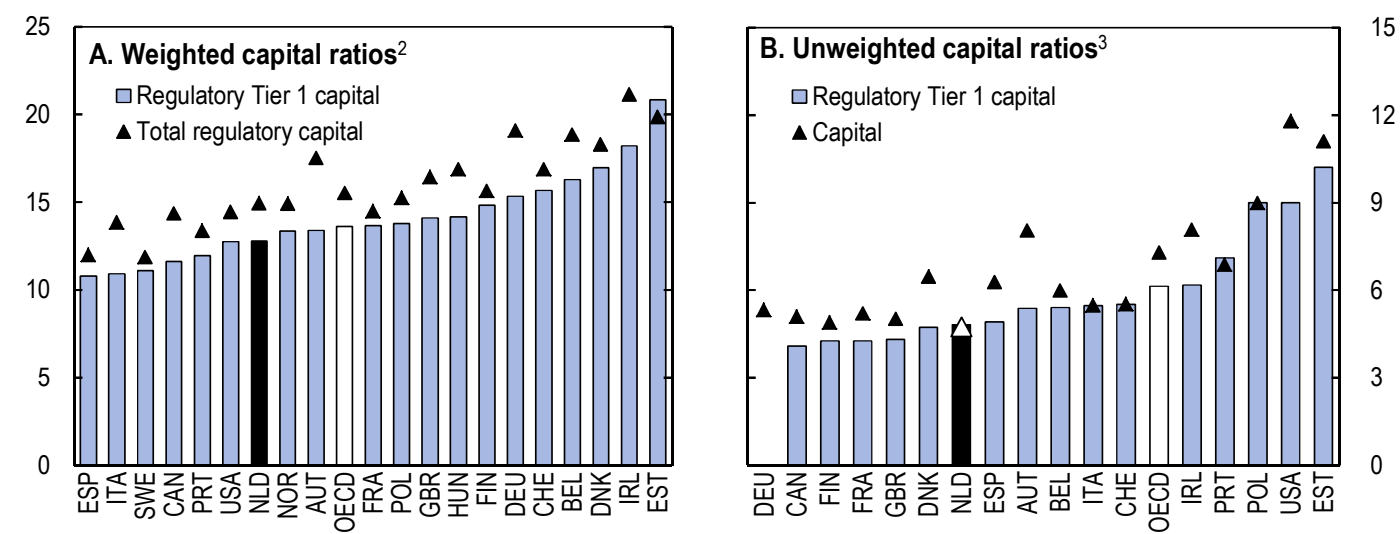

1. Or latest quarter available. 2012 for Switzerland. Regulatory capital compiled in accordance with the guidelines of Basel II (except for the United States where Basel I is applied). For France there is no information available on Basel standards. The banking sector covers banks and other deposit takers (units engaging in financial intermediation as a principal activity).

2. Capital to risk-weighted assets. The OECD aggregate covers 30 countries.

3. Capital to total assets that are not risk weighted. Capital is measured as total capital and reserves as reported in the sectoral balance sheet. The OECD aggregate covers 29 countries for regulatory Tier 1 capital and 26 for capital.

Source: IMF (2014), Financial Soundness Indicators (database), International Monetary Fund, March.

Figure 4. Financial buffers to absorb losses from non-performing loans are relatively weak Per cent, third quarter of $2013^{1}$
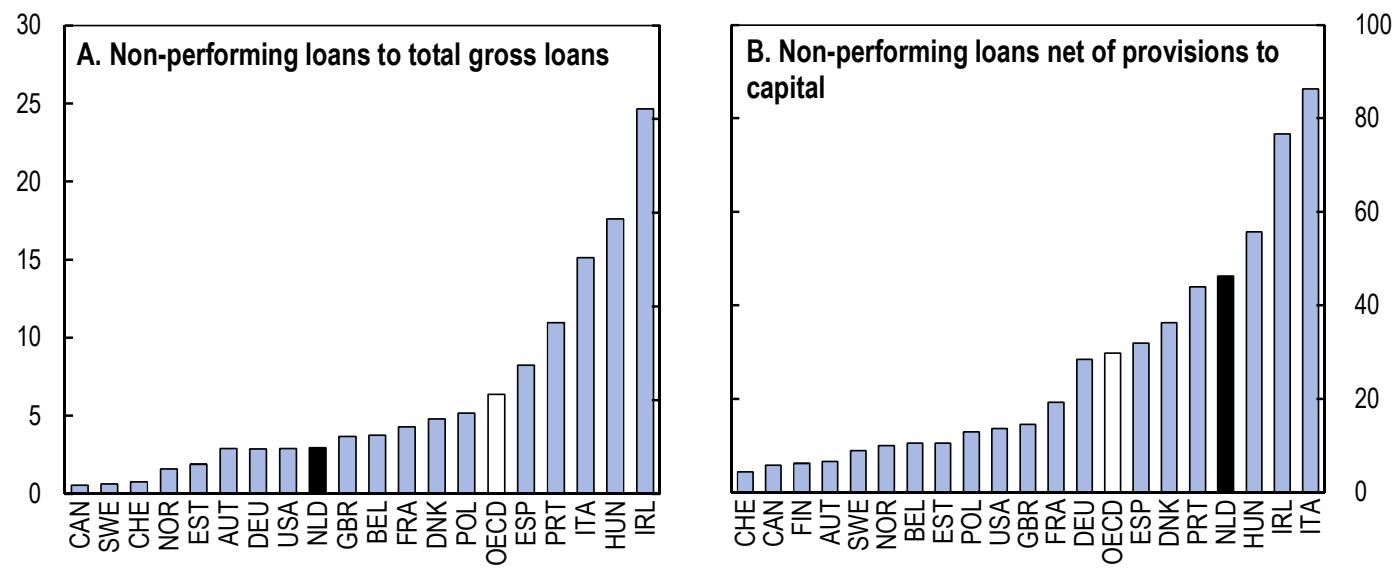

1. Or latest quarter available. 2012 for Germany and Switzerland. The OECD aggregate covers 29 countries in panel A and 30 in panel B.

Source: IMF (2014), Financial Soundness Indicators (database), International Monetary Fund, March.

How to read this figure: Potential reduction of banks' capital to absorb losses assuming that all non-performing loans net of loan-loss provisions are written off.

\section{The banking sector is facing new risks}

The weak economy is increasing non-performing loans

Corporate defaults in the non-financial sector and growing unemployment are weighing on banks' balance sheets. NPLs have steadily increased for small and medium-sized enterprises (SMEs) to about 6\% and NPLs for large companies have been broadly flat at around 3.5\% since mid-2009 (Figure 5, Panel A). NPLs for residential mortgages have remained at a low level of close to $1 \%$ when unemployment has more than doubled (Figure 5, Panel B). However, households have had more difficulties to service their consumer debt. A lower debt service burden as interest rates have dropped, a low amortisation of 
mortgages and generous social safety nets could have helped to withstand the downturn. Another complementary explanation is that perhaps problem loans could be underestimated, notably because there is no uniform definition of NPLs.

Figure 5. The crisis is weakening banks' balance sheets ${ }^{1}$

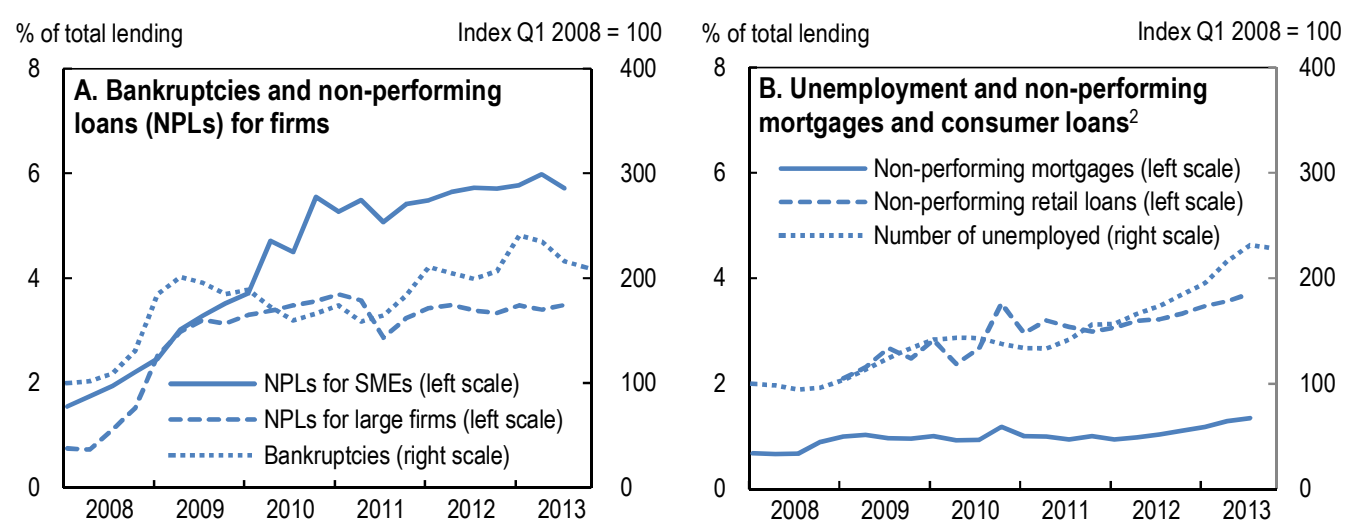

1. Data on non-performing loans (NPLs) is based on a sample of large banks. NPLs are defined as loans with payment arrears of at least 90 days. NPLs for large firms include commercial property loans and exclude small and medium-sized enterprises (SMEs). Bankruptcies refer to businesses and institutions (i.e. single-owner companies and trading partnerships). For bankruptcies data from third quarter of 2012 onwards are provisional.

2. Residential mortgages.

Source: De Nederlandsche Bank, Statistics Netherlands (2014), "Security and Justice", Statline, March and OECD (2014), OECD Economic Outlook: Statistics and Projections (database), March.

\section{Household repayment difficulties could be expected to rise}

Despite low NPLs, mortgages with payment difficulties have been trending upwards. According to the Dutch Credit Registration Office (BKR), the number of mortgages in arrears by 120 days or more reached almost 92000 in October 2013 and increased by $13 \%$ over the previous six months. The number of calls on the National Mortgage Guarantee (NHG) scheme - which insures a fifth of mortgages against residual claims left after a sale of a property in case of unemployment, disability, divorce or death of partner - rose from less than 1000 to 4500 between 2008 and 2013. Forced sales have so far been contained at around 2000 to 2500 per year. However, according to the BKR some 740000 people have had debt repayment problems based on data published in January 2014. Of around 8.5 million people in the credit register, close to $8.5 \%$ were falling behind payment schedules by at least two months. This suggests that growing payment difficulties on consumer loans could feed into mortgage loans at some point.

Defaults have been contained so far but a large number of them cannot be excluded if economic conditions deteriorate further and households with negative home equity change behaviour (IMF, 2013b). House prices peaked in August 2008 and have been continuously falling since then. From peak, the fall in nominal terms has reached $20 \%$ while the fall in real terms is nearly $30 \%$. Around $35 \%$ of all homeowners and $40 \%$ of households with a mortgage - mostly young people who bought their dwellings over the past decade - now have negative home equity due to falling house prices and high loan-to-value ratios on their mortgages. Despite some signs of stabilisation, the housing market is at depressed levels (Figure 6). While being rough indicators as they do not include the cost of capital, price-to-rent and price-to-income ratios suggest that additional downward price adjustment cannot be excluded (Figure 7). Exposure to changes in interest rates is high. In 2008, around half of all mortgages had a remaining fixed interest period of four years or less, reflecting the fact that around $70 \%$ of borrowers tended to fix the interest rate for a maximum period of 10 years (DNB, 2009). A hike in the policy rate by 300 basis points rate would increase the median debt service-to-net income ratio to nearly $25 \%$ and more than a fourth of households would face a high ratio in excess of $40 \%$ (ECB, 2013b). 
Figure 6. The housing market is depressed
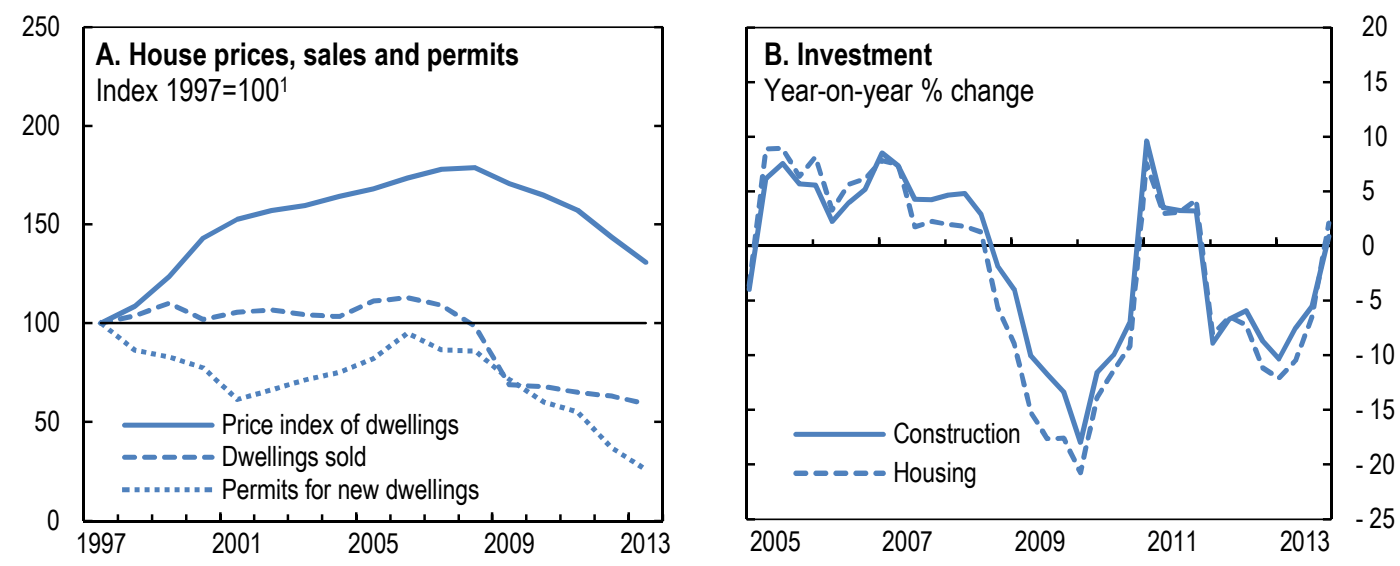

1. Price index of dwellings is deflated by consumer prices. Data refer to existing own homes except for permits.

Source: Statistics Netherlands (2014), "Construction and Housing", Statline, March and OECD (2014), OECD Economic Outlook: Statistics and Projections (database), April.

Figure 7. House prices in relation to incomes and rents across the OECD

Per cent of over or under-valuation relative to long-term averages, fourth quarter of $2013^{1}$

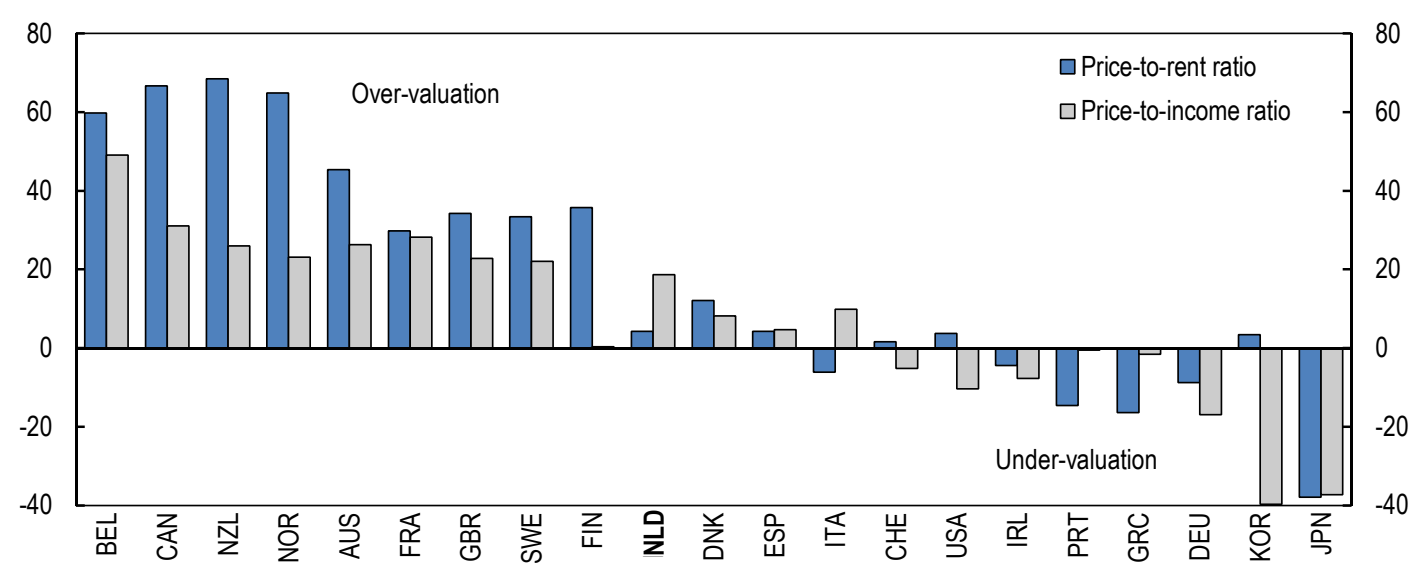

1. Third quarter of 2013 for Belgium, Italy, Japan and New Zealand. Countries are ranked by the average of the two indicators, from highest to lowest. The long-term average covers the period from 1980 (or earliest available date) to the latest available quarter.

Source: OECD (2014), OECD Housing Prices Database, Economics Department, April.

\section{Higher risks lie ahead when interest-only mortgages will fall due}

The low ratio of NPLs for mortgages is due to the fact that many of these loans are not regularly amortised for a long period, typically 30 years. These mortgages could become non-performing when borrowers have to pay the principal and are unable to do so. There are several types of mortgage products in the Netherlands. Around 35\% of outstanding mortgages are 100\% "interest-only" loans. They do not have any mechanism attached for the build-up of the principal, which has to be repaid in full only at maturity once a deferment period expires. Approximately $25 \%$ are savings-based mortgages that are linked to a savings account in a bank or an insurance company to accumulate the principal that needs to be redeemed at maturity, although there is no regular amortisation. There are only $5 \%$ of mortgages subject to regular (linear or annuity) amortisation. Finally, nearly 35\% of outstanding mortgages combine two or more products, for instance may have a $50 \%$ part linked to a savings account in a bank or an insurance 
company for the accumulation the principal, and a 50\% part which is "interest-only". Given the mortgage product mix, it is estimated by the DNB that de facto around 55\% of the overall loan portfolio is "interestonly", against less than $10 \%$ in the mid-1990s, and that the share of loans linked to a savings account with a lump sum repayment of the principal reached 30\% in 2012 (Figure 8). At the same time, the market share of regularly amortising mortgages fell from $50 \%$ to $15 \%$.

Figure 8. Market share of mortgages with deferred amortisation has expanded sharply

Per cent of total ${ }^{1}$

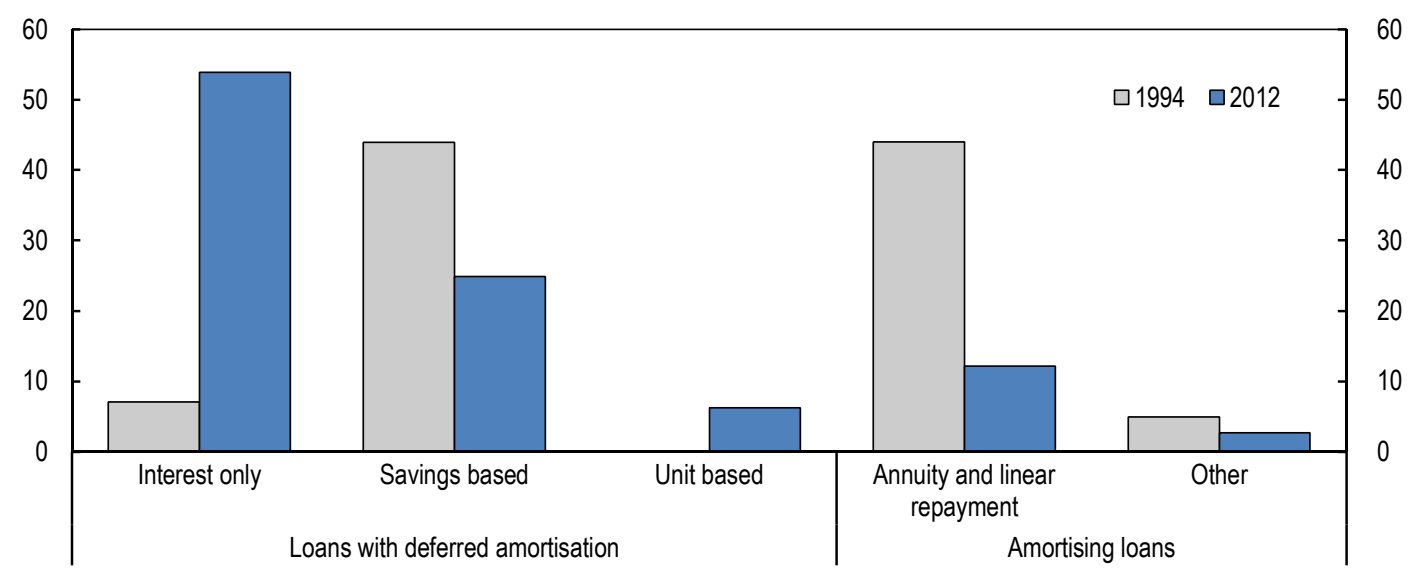

1. Unit based mortgages were zero in 1994.

Source: De Nederlandsche Bank.

According to the DNB, many households are not accumulating equity sufficiently to pay back their mortgage debt (DNB, 2012; IMF, 2011a). This applies to interest-only, but also to savings-based mortgages. This is corroborated by negative voluntary (made on the top of mandatory contributions to pension funds) household saving ratios since 2003. Interest-only mortgages, also a concern in the Nordic countries (IMF, 2013c), blunt the amortising behaviour, may exploit borrowers' short-sightedness and their gaps in financial literacy and create macro-prudential risks. The share of maturing interest-only portfolio will begin to rise sharply in 2025. As a result, households' difficulties to repay their mortgage capital could expose banks to significant losses, even though risks are lower for elderly borrowers who have high net wealth. The total exposure of the Dutch banking sector to mortgage loans accounts for close to $30 \%$ of total banks' balance sheets. Household gross debt has risen to historically high levels, reaching nearly $290 \%$ of disposable income and almost $130 \%$ of GDP in 2012. This contrasts with a more contained indebtedness of the non-financial corporate sector (Figure 9). Mortgage growth has continued at a decelerating pace during the crisis. The ratio of household debt to gross disposable income increased by almost 50 percentage points between 2007 and 2012, while the ratios were constant or dropped in other OECD countries. 
Figure 9. Debt of households and non-financial corporations

Per cent ${ }^{1}$

$\square 2012$

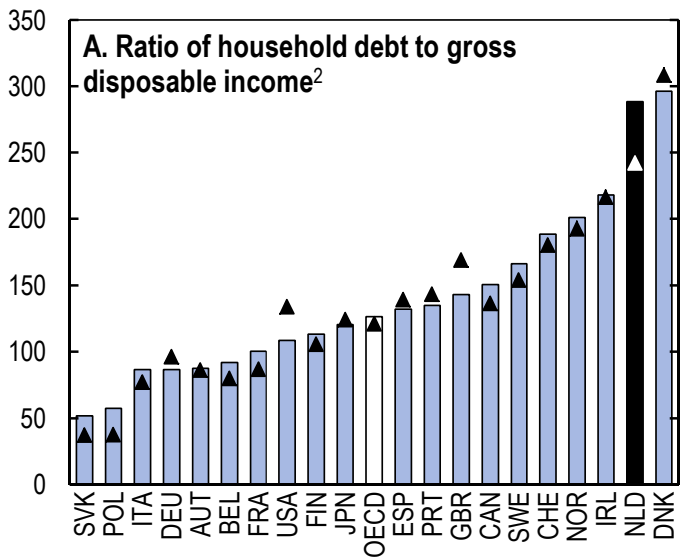

$\mathbf{\Delta} 2007$

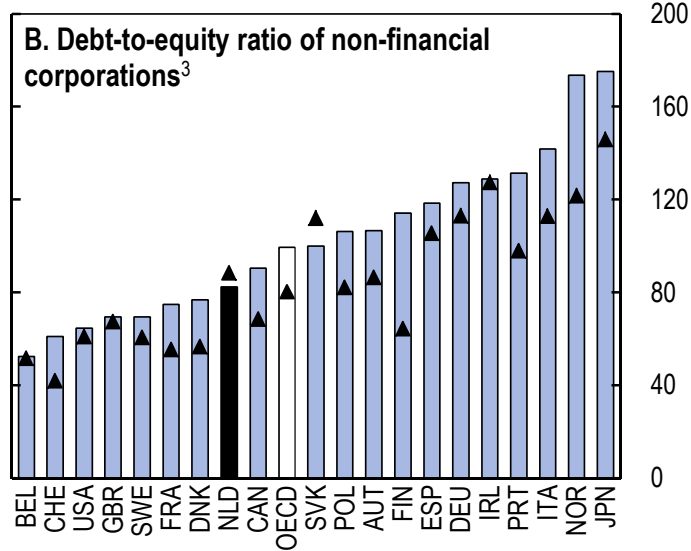

1. Debt is calculated as the sum of the following liability categories, whenever available/applicable: currency and deposits, securities other than shares, except financial derivatives, loans, insurance technical reserves and other accounts payable. Nonconsolidated data from financial balance sheets.

2. Debt of households including non-profit institutions serving households. The OECD aggregate covers 29 countries. 2011 instead of 2012 for Japan and Switzerland. 2010 instead of 2012 for Canada.

3. Debt as a percentage of shares and other equity. This indicator measures the financial leverage or the extent to which activities are financed out of their own funds. The OECD aggregate covers 31 countries. 2011 instead of 2012 for Japan and Switzerland.

Source: OECD (2014), OECD National Accounts Statistics (database), March.

The key issue is whether households will have saved enough money to repay the capital. Currently, full redemption at maturity is not guaranteed because the borrower is not obliged to accumulate sufficient capital to pay back the mortgage. In principle, households can build up earmarked savings to repay the principal. However, given interest rate and stock market developments over the past decade and uncertainties surrounding future developments, incentives to step up savings could be low. On the other hand, redemptions have somewhat increased more recently driven by lower interest rates on saving accounts and a cancellation of penalties for early repayments. Tax incentives for savings products have also aimed to offset negative effects of mortgage interest deductibility on principal accumulation, further weighing on the public purse. For instance, since 2007, capital accumulation via bank savings accounts has been encouraged through tax exemptions, which had been allowed only for insurance products previously. Lately, the authorities have adopted additional tax reliefs to encourage the repayment of existing mortgage debt. The interest on residual mortgage debt left after a sale of a dwelling has been made tax-deductible for up to ten years and the limit for tax-free gifts for house purposes, including for debt repayment, increased to EUR 100000 . However, these measures are not targeted to borrowers most in need and can be also viewed as a way to indirectly "bail-out" borrowers at the cost of the taxpayer.

Alternatively, households could use their accumulated wealth to repay the capital falling due. They have significant assets on average, but their composition and distribution reveal that they cannot easily be used to repay debt. First, the composition of assets has become more illiquid over time (Figure 10). Notwithstanding property assets, overall financial assets still largely exceed liabilities. Yet when housing and pension assets are excluded, remaining assets exceed debt only marginally. Liquid assets to make an early repayment of debt or to offset potential increases in debt servicing costs are low, also internationally (IMF, 2013c). 
Figure 10. Household balance sheets have become more stretched

Per cent ${ }^{1}$

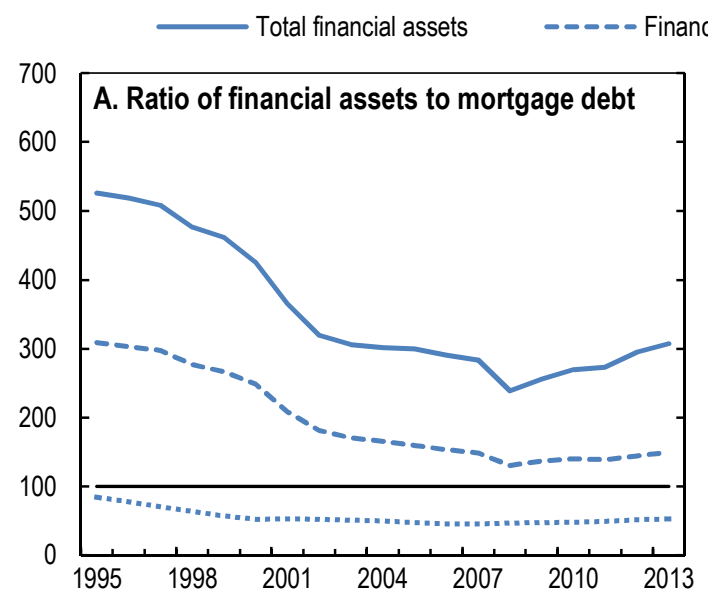

1. Figures from 2011 onwards are provisional. Financial assets include savings and other deposits, shares and other equities, the net equity of households in the pension funds reserves of resident pension funds and life insurance companies as well as the net equity of households in the life insurance reserves of resident and non-resident pension funds and life insurance companies. Liquid assets refer to savings deposits and other deposits that are all the savings of individuals and deposits (in euros and foreign currency) at any resident and non-resident bank, which are not immediately transferable without restrictions.

Source: Statistics Netherlands (2014), "Macroeconomics: Sector accounts", Statline, April.

Second, the distribution of assets shows that young and prime-age households are particularly exposed to adverse developments in the housing market, and risks have increased since the beginning of the crisis. The share of debtors aged below 35 with negative home equity was above $70 \%$ on 1 January 2013, latest data available (Figure 11, Panel A). For borrowers aged between 25 and 35, the total value of mortgage debt was higher than the corresponding value of housing assets (Figure 11, Panel B). Total debtto-assets ratios were high (Figure 11, Panel C) and net wealth as a share of disposable income was low (Figure 11, Panel D) for the young, and the opposite was true for seniors (pension assets are disregarded in both cases as relevant data by age are unavailable). 
Figure 11. Risks are concentrated among young and prime-age households

Per cent of households by age of the main breadwinner, data at 1 January ${ }^{1}$
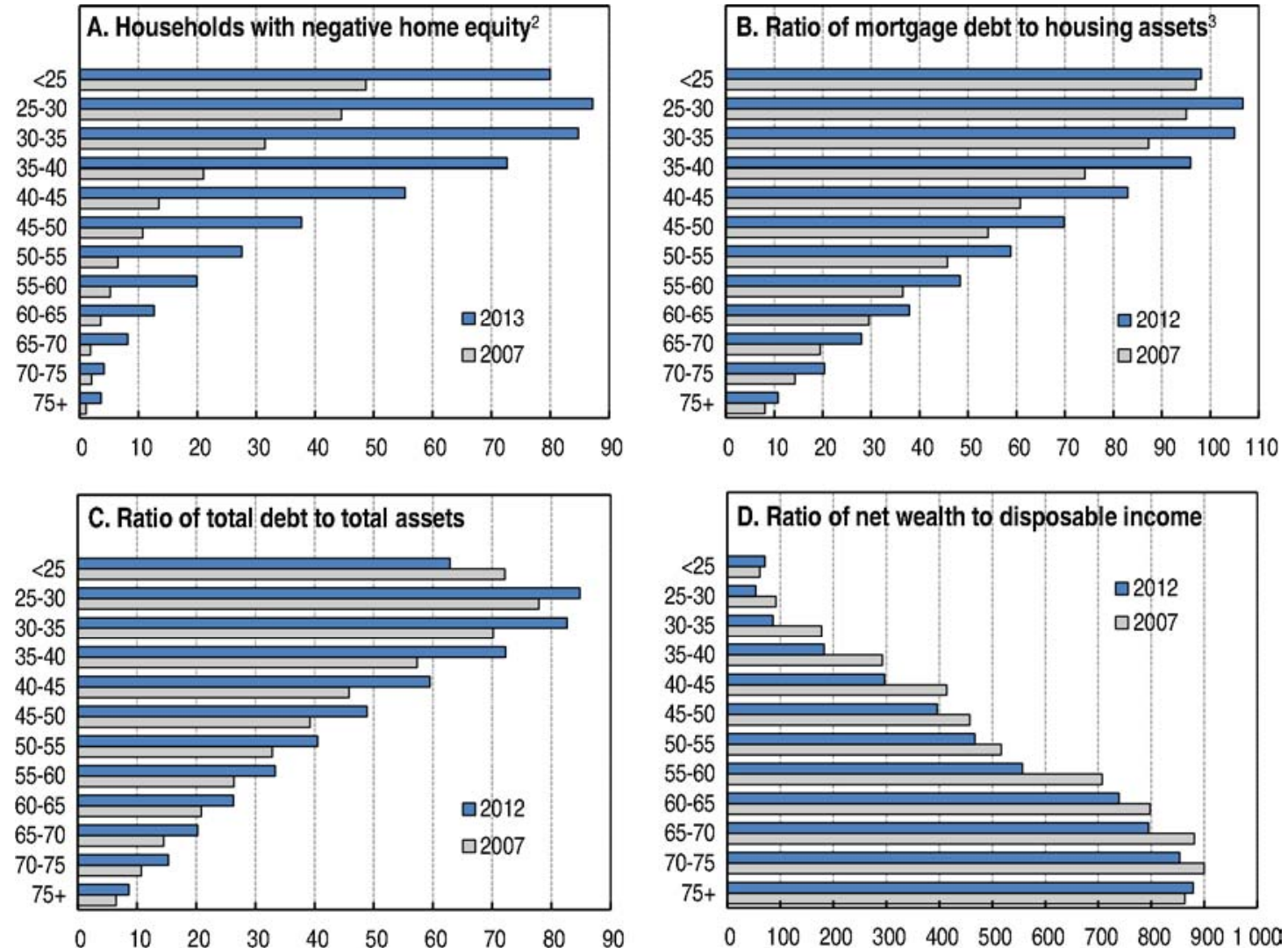

1. Assets include current and saving accounts, bonds and stocks, own-home, business assets and other possessions, but exclude pension assets as relevant data by age are unavailable. Figures from 2012 onwards are provisional.

2. Home-owning households with a mortgage.

3. Housing assets refer to property owned and used as a main residence. Mortgage debt is associated with home ownership and represents the value of the debt on which interest is payable.

Source: Statistics Netherlands (2014), "Income and Spending", Statline, March.

\section{Making the banking sector more resilient}

\section{Reducing risks from a large and concentrated banking sector}

In the case of another financial crisis, the Netherlands would be particularly exposed as its banking sector is one of the largest in the OECD. Total assets are above $400 \%$ of GDP based on national account data (Figure 12), with assets of special purpose vehicles (involved heavily in mortgage lending via securitisation) amounting to 50\% of GDP at the end of 2012. A vulnerable, large and concentrated banking sector threatens the taxpayer through bailouts. Moreover, the nature of financial deepening in the Netherlands - related to international exposure, a shadow banking sector and mortgage lending - could explain potential risks related to the large financial sector. 
Figure 12. The large banking sector poses systemic risks

Total assets in per cent of GDP, $2012^{1}$
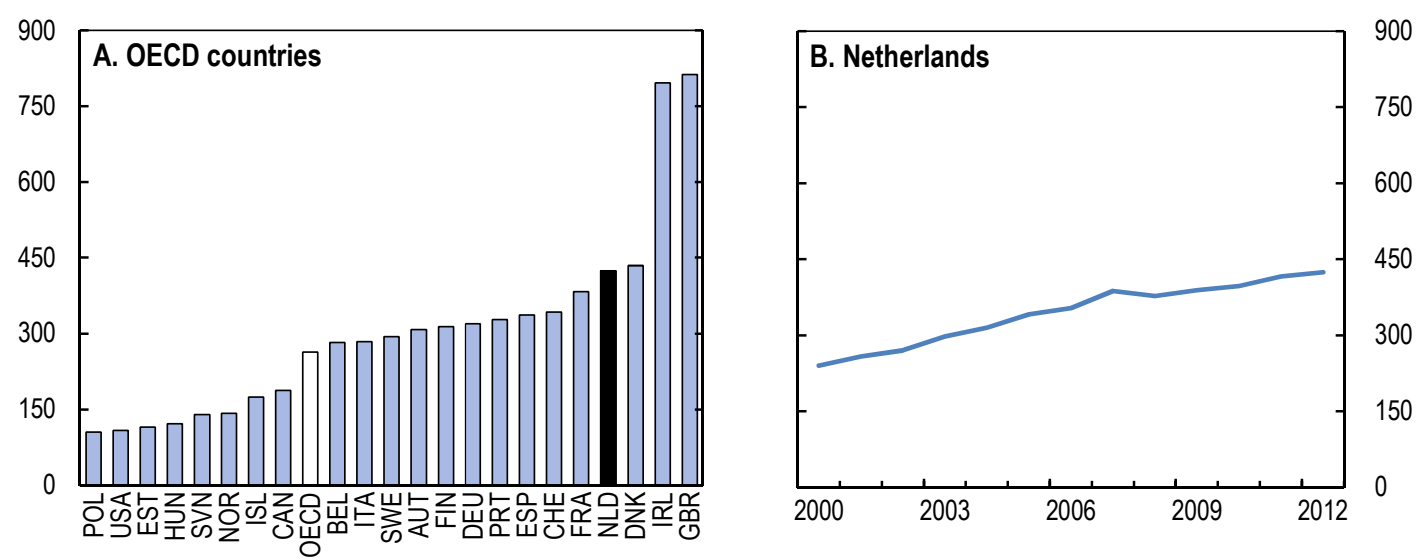

1. Figures for Germany, Ireland, Italy, Poland and United Kingdom also include central bank assets. The OECD aggregate covers 31 countries. 2011 for Switzerland. Non-consolidated data from financial balance sheets.

Source: OECD (2014), OECD National Accounts Statistics (database), March.

The Dutch authorities have encouraged the development of the Netherlands as an international financial centre. The value-added of this sector amounts to almost $8 \%$ of the GDP and is even higher now than in the pre-crisis period (Figure 13). While some business operations are justified by the fact that banks have continued to serve large multinational Dutch companies abroad (Schoenmaker and Werkhoven, 2013), this explains only a small part of the growth in international activities. Financial internationalisation has proven to be profitable in the short-run, but it has led to an extensive exposure to cross-border risks. Liquidity risks were high as banks relied on short-term funding, such as inter alia funding by the US money market funds (Fitch Ratings, 2013).

Figure 13. Value added of the financial sector

Value added share relative to the total economy ${ }^{1}$
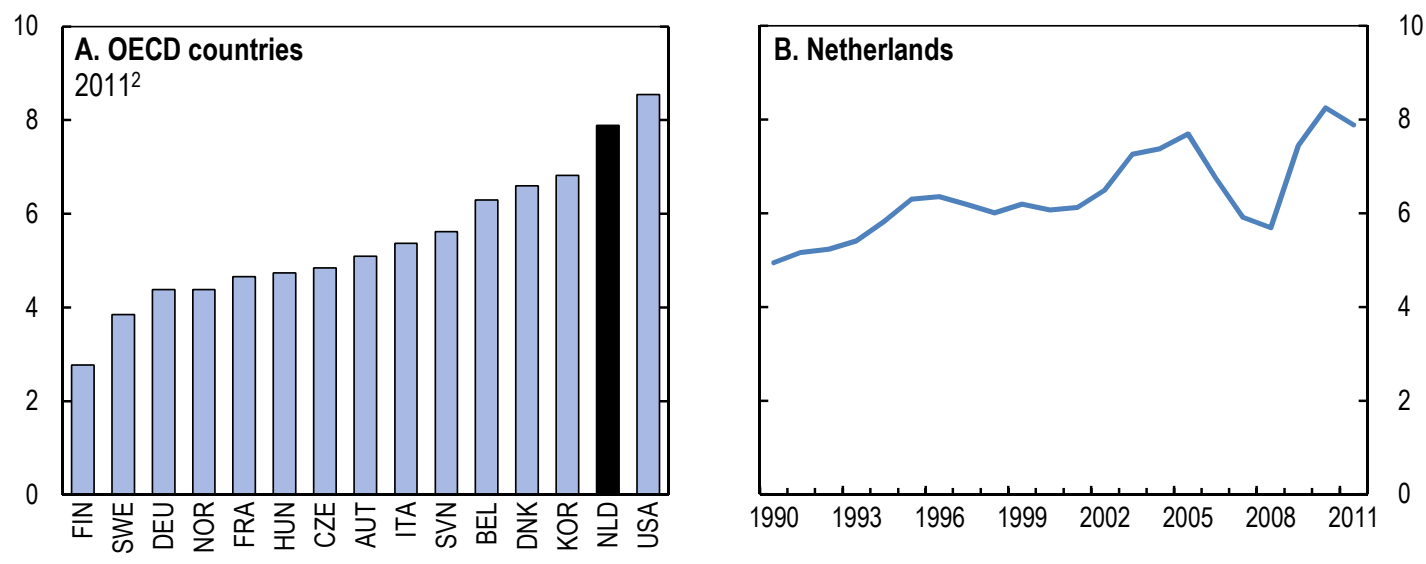

1. Financial sector covers financial and insurance activities (including activities auxiliary to financial service and insurance activities) based on the International Standard Industrial Classification of all economic activities, Revision 4 (ISIC Rev. 4).

2. 2010 for Hungary, Korea, Slovenia and United States.

Source: OECD (2014), STAN: OECD Structural Analysis Statistics (database), March. 
Foreign claims of Dutch banks (which include claims of their foreign subsidiaries) have declined from a peak of 300\% of GDP in 2007 to 150\% in 2013 (Figure 14). Therefore, currency mismatches of Dutch banks have been significantly reduced. US money market funds, the largest suppliers of dollar funding to non-US banks, have experienced a run in the wake of the Lehman collapse and a "quiet run" (slower and longer withdrawal of funds) during the euro-crisis in 2011. The latter led to a sharp decline of their exposure to Dutch banks, which nevertheless managed to attract USD funding via other channels (Baba et al., 2009; Chernenko and Sunderam, 2012). Money market funds have returned to Netherlands and other core countries in the euro area at the end of 2013, but this means a renewed reliance on short-term funding for Dutch banks. In September 2013, liabilities of Dutch banks on a consolidated basis to the US money market funds amounted to EUR 20 billion or $30 \%$ of total liabilities to the United States on a nonconsolidated basis (consolidated data is not available).

Figure 14. Foreign claims of banks are large but have been reduced by half

Per cent of GDP ${ }^{1}$
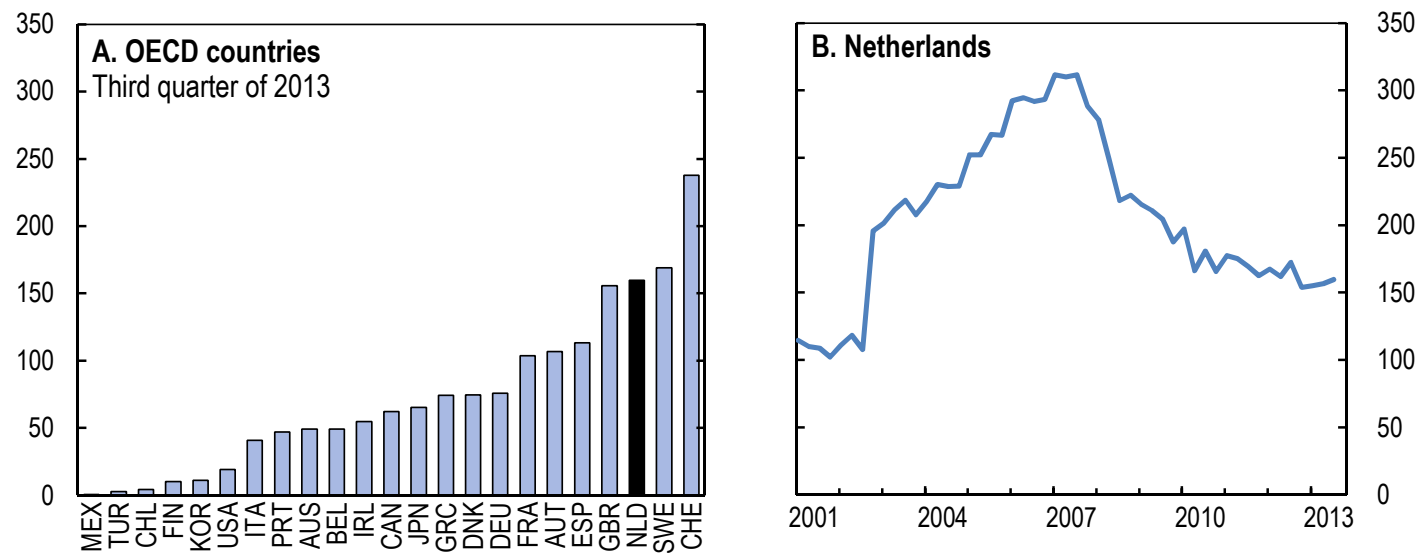

1. The BIS consolidated banking statistics (on the immediate borrower basis) report banks' on-balance-sheet financial claims on the rest of the world and provide a measure of the risk exposure of lenders' national banking systems.

Source: BIS (2014), "Consolidated Banking Statistics", BIS Statistics, Bank for International Settlements, March.

The large size of the Dutch banking sector is also explained by a close interconnectedness with the large shadow banking sector. According to the Financial Stability Board (FSB, 2012), the Dutch shadow banking sector (defined as non-bank financial institutions that cannot be categorised as insurance corporations, pension funds or public sector financial entities) amounts to $490 \%$ of GDP, one of the highest shares in the OECD. Almost two thirds of these assets comprise special financial institutions (SFIs) that are typically owned by foreign multinationals to attract external funding and facilitate intra-group transactions (Figure 15). An important reason for their existence is tax planning, which is reflected in a low implicit corporate income tax rate as the Netherlands has notably an extensive tax treaty network. A large share of SFIs is non-financial institutions and is assessed by the central bank to have a low shadow banking content (Broos et al., 2012). Nevertheless, there could still be some interconnectedness between the rest of the shadow banking sector and banks as the latter have large claims on non-bank financial intermediaries (almost 20\% of banks' assets) and also depend on them for funding (10\% of liabilities). This can potentially lead to a transmission of shocks between the two sectors and this risk has increased since the global crisis as interconnectedness has further intensified (FSB, 2012). 
Figure 15. Structure of the shadow banking sector

Per cent of total size of other financial intermediaries, end $2011^{1}$

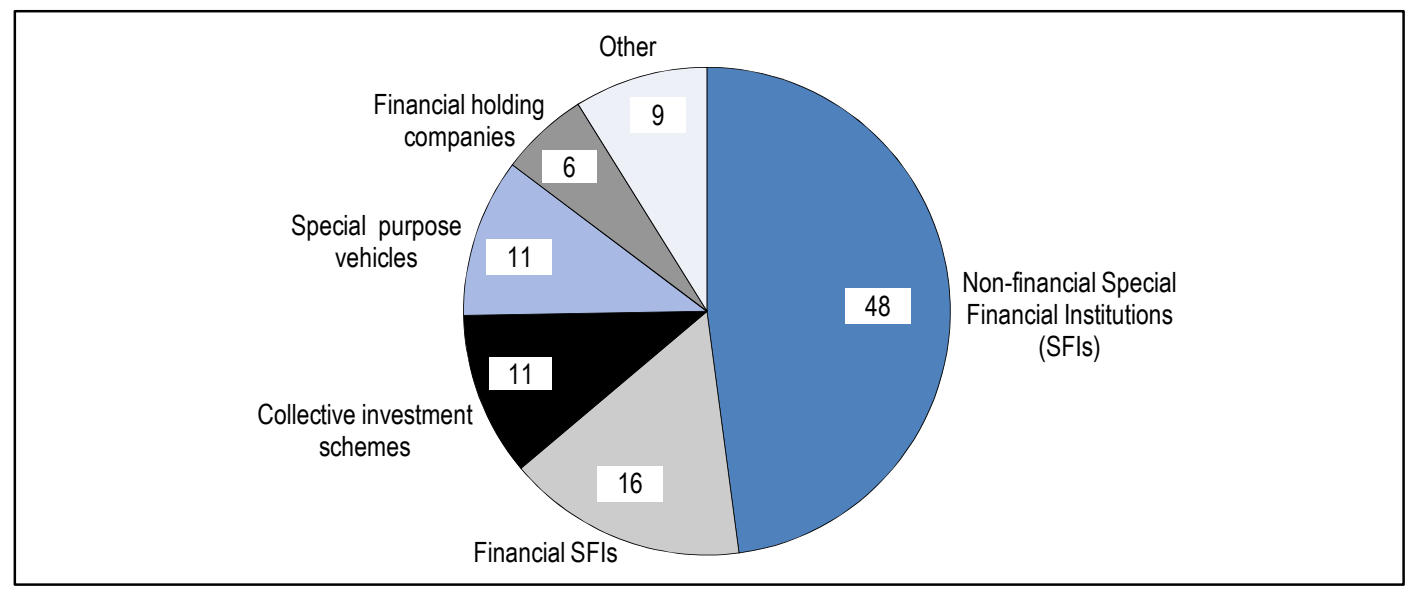

1. Provisional data. Figures for non-financial and financial SFIs are estimates based on data from 2010. For SFls the provisional total figure published by Statistics Netherlands for 2011 is EUR 2028 billion. SFls are established by foreign multinational corporations for the purpose of channelling financial assets from one country to another. The criteria applied to definition of SFls include whether the entity is domiciled in the Netherlands, has a predominantly foreign shareholder base and has a balance sheet consisting primarily of channelled funds. Other includes money market funds, finance companies, hedge funds, private equity and investment firms among others.

Source: M. Menno Broos, K. Carlier, J. Kakes and E. Klaaijsen (2012), "Shadow Banking: An Exploratory Study for the Netherlands", DNB Occasional Studies, Vol. 10, No. 5, De Nederlandsche Bank.

The banking system is also very concentrated (Figure 16). The four largest banks - ABN AMRO, ING, Rabobank and SNS Reaal - account for $80 \%$ of assets and are all classified as systemically important by the regulator. Moreover, the first three of them belong to 39 major cross-border European banks and the largest bank, ING (with a total value of assets of about $160 \%$ of GDP), is among the 29 systemically important financial institutions worldwide. The existence of such systemically important institutions poses risks because their disorderly failure would cause significant disruption to the wider financial system. Consequently, they have benefited from implicit government guarantees (that are acknowledged by rating agencies that document the highest level of state support), allowing them to have simultaneously lower capital buffers and lower funding costs. This distorts the level playing field by providing big banks with a comparative advantage over smaller institutions, hence creating incentives to grow even bigger.

Figure 16. Concentration of the banking sector

Assets of three largest banks as a share of assets of all commercial banks, per cent, $2011^{1}$

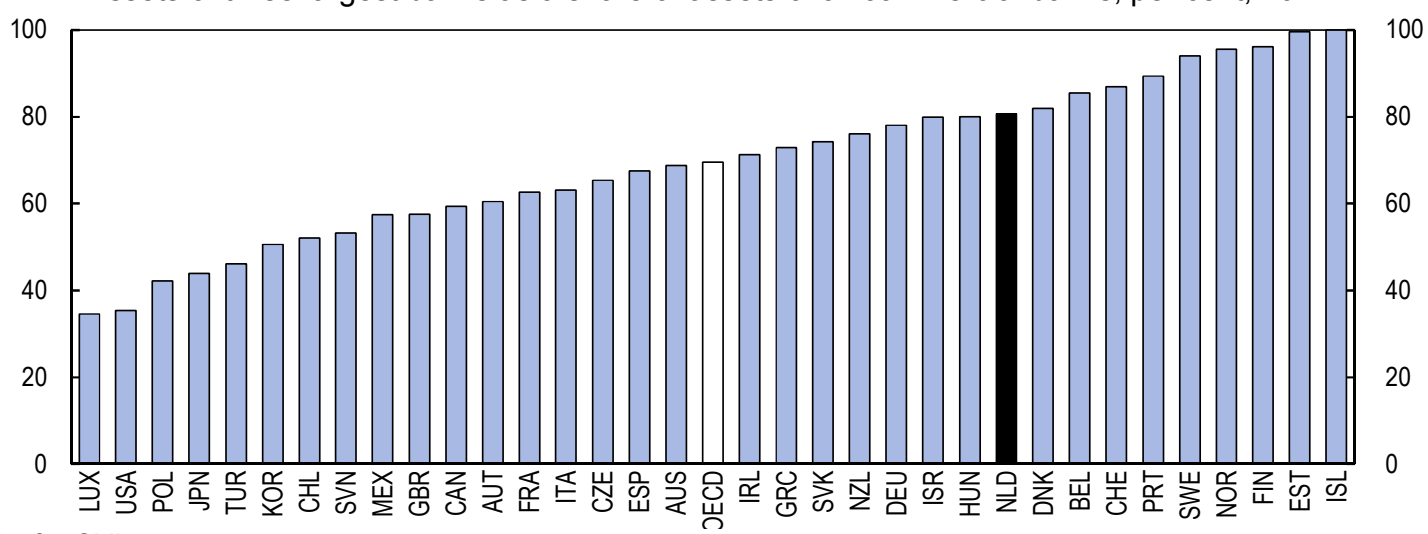

1. 2007 for Chile.

Source: World Bank (2014), Global Financial Development (database), March. 
Household credit constitutes more than $60 \%$ of overall bank credit, which has led to one of the highest levels of household indebtedness in the OECD. Spurred by generous interest rate deductibility, state guarantees and lenient lending practices related to insufficient consumer protection, such credit supply might have been achieved at the expense of servicing the domestic enterprise sector. Although further empirical evidence is needed, it appears that as banks had been allocating more lending to households and comparatively less to the corporate sector, the contribution of total factor productivity (TFP) to potential output growth fell in many OECD countries in the run-up to the crisis (Figure 17). In the Netherlands, this contribution turned around at the end of the 1990s when the housing market started to overheat and house prices exceeded long-term averages in relation to incomes and rents.

\section{Figure 17. The allocation of lending has been skewed towards households ${ }^{1}$}
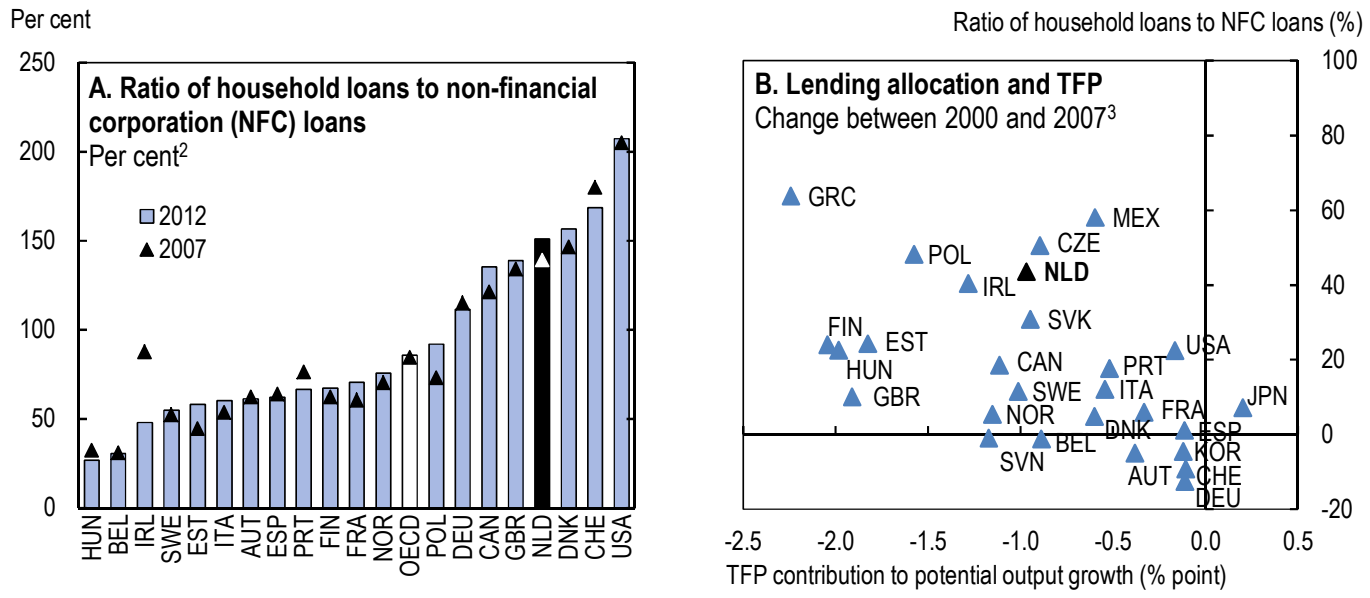

1. Households include non-profit institutions serving households. Ratio of household loans to NFC loans is non-consolidated data from financial balance sheets. TFP: Total factor productivity.

2. The OECD aggregate covers 29 countries. 2011 instead of 2012 for Switzerland.

3. 2002-07 for Estonia and Korea. 2001-07 for Ireland and Slovenia.

Source: OECD (2014), OECD National Accounts Statistics and OECD Economic Outlook: Statistics and Projections (databases), March.

Empirical research shows that to be beneficial for growth, financial deepening has to operate via enterprise credit and not household debt (Beck et al. 2012; Chakraborty et al., 2013). In addition, while the availability of finance is crucial for economic growth, an oversized financial sector could have no effect or even a negative impact on economic activity (Aghion et al. 2005; Arcand et al., 2012). Recent empirical literature on finance and growth suggests that there are decreasing returns to financial development and that policymakers should focus on lending to firms instead of consumers (Bijlsma and Mocking, 2014). Yet, on the other hand, higher homeownership rates and housing consumption could also raise households' wellbeing.

Several approaches to breaking the link between "too big to fail" banks and low capital ratios are currently being discussed in the Netherlands and internationally. Conceptually, the solution can be achieved via three complementary reforms: $i$ ) increasing of capital requirements for large banks to minimise the probability of their failure and to ensure that they internalise the costs of systemic risks related to their liquidation; ii) restricting the business scope of systemically critical institutions by separating their investment divisions; and iii) establishment of a framework that allows an orderly resolution of large institutions. 
ECO/WKP(2014)52

\section{Accumulating higher capital buffers to internalise and absorb risks}

The authorities plan to phase in new capital requirements between 2014 and 2019, which consist of Basel III regulations and the EU Capital Requirements Directive IV. In terms of risk-weighted assets, this includes a minimum total capital ratio of $8 \%$, a $2.5 \%$ conservation buffer (in form of Common Equity Tier 1 [CET 1] capital), a 0-2.5\% countercyclical buffer (in form of CET 1) and a systemic important bank (SIB) buffer of up to 3\% (in form of CET 1). The DNB is considering a countercyclical buffer of $0-2.5 \%$ and a SIB buffer of 1-3\% of risk-weighted assets (DNB, 2013b). A 1\% Pillar 2 surcharge is also planned. Overall, this would lead to a total required capital ratio for systemic banks of 15 to $17 \%$ in good times and 12.5 to $14.5 \%$ in bad times.

New capital standards could be further strengthened by ensuring a maximum implementation of the SIB buffer of 3\% for key banks. Yet a stronger buffer could be envisaged as well, reflecting the vulnerability of the economy to banks' size, concentration, international exposure and reliance on shortterm funding. This would be in line with new regulations in Switzerland and Sweden, two other OECD countries that are home to large international banking industries and that are opting for high capital standards. The two largest Swiss banks are required to hold 19\% capital (Tier 1 and Tier 2). The Riksbank recommends that four major Swedish banks should hold 12\% of the CET 1 capital from 1 January 2015 and this requirement will increase when countercyclical buffers are triggered (Sveriges Riksbank, 2013).

The calculation of risk-weighted capital ratios relies on internal models that are bank specific and riddled with uncertainty (BIS, 2013a). Experts argue that international banks engage in lowering risk weights for some classes of assets, which improves regulatory capital adequacy ratios but undermines banks' resilience to losses (Haldane, 2011; Alloway, 2011). The DNB also finds wide disparities between the risk-weighted assets as banks tend to give different weightings to credit risks, even when they involve the same types of loan to the same counterparties. Moreover, internal bank models could be difficult to assess because the DNB does not have access to household credit registry data and because enterprise credit registry data is not collected. To address problems related to risk weights, the DNB conducts themebased research on risk-weighting and model assessment and requires banks to harmonise their risk weights. Beyond Basel rules, it could additionally require banks to apply higher and floor risk weights for some assets classes deserving special attention. For example, risk weight for mortgages have recently been proposed to be raised from 0.15 to 0.25 in Sweden, which should create incentives for banks to issue loans with lower loan-to-value (LTV) ratios as otherwise banks will need to strengthen their capital to sustain lending.

In its "Banking vision paper" the Dutch government proposes to introduce a $4 \%$ leverage ratio for systemically important financial institutions (Government of the Netherlands, 2013a) and the Netherlands is the first euro area country doing it. This is a welcome step, but current discussions at the international level on the definition of the leverage ratio need to be taken into account when defining its appropriate level. An ambitious leverage ratio is justified given the size of the largest banks, and would ensure that banks do not circumvent capital requirements. This would also mitigate errors related to models and new products for which risk weights are not precise (Blundell-Wignall and Roulet, 2013). Importantly, the denominator of the leverage ratio should include not only total assets but also off-balance sheet items. While a $5 \%$ leverage ratio would require $4.5 \%$ of GDP of additional capital (OECD, 2013a), it would bring Dutch banks closer to the OECD average leverage ratio of $6 \%$ for Tier 1 capital (Figure 13, Panel A). The US regulator has proposed that the eight largest banks hold a 3\% supplementary leverage ratio (equity divided by assets) on top of the $3 \%$ minimum ratio required for smaller banks. Polish banks are required to have a leverage ratio of $9 \%$ before distributing dividends. In Switzerland, there is a discussion to increase the leverage ratio from $5 \%$ to $6-10 \%$ for the two largest banks. Indeed, several academic experts advise leverage ratios of at least 9-10\% (Admati, et al. 2010; Ratnovski, 2013). Finally, leverage ratios of 10-20\% 
have been common for Dutch banks for most of the 20th century, before the start of deregulation in the 1970s, without compromising the supply of credit (Berben et al., 2010).

Despite having a beneficial effect on banks' refinancing costs, a higher capitalisation of banks could have a potential negative impact on growth in the short term if banks reduce lending rather than raise the level of capital. Banks' funding costs were insensitive to their level of capital before the crisis, but the crisis has strengthened market discipline and currently banks with higher capital buffers enjoy lower funding costs (Admati et al., 2010; Bank of England, 2013). There is some evidence that during the 20th century, there was no relationship between the level of capital on the one hand, and loan pricing and loan growth on the other (The Economist, 2012). Simulations by the Bank for International Settlements (BIS) indicate that each one percentage point increase in the capital ratio raises loan spreads by 13 basis points, but the net impact on growth is positive in the medium term due to enhanced resilience of the financial sector and lower crisis probability (BIS, 2010). Similar effects are found for the Netherlands by Berben et al. (2010).

Capital buffers should be raised by increasing the level of capital rather than by scaling back lending. Issuance of shares and increased retained earnings through lower dividend distribution and reduction of costs should bolster high-quality capital. In particular, there is scope to reduce salaries in the banking sector (DNB, 2013b). The government is considering introducing a limit on performance-related bonuses at $20 \%$ of salary which could favour financial stability by lowering risk-taking and by encouraging a faster accumulation of capital, but banks may compensate by raising salary. Rabobank has announced a voluntary temporary freeze in pay and bonuses until 2015.

\section{Strengthening bank balance sheets with more provisioning}

In the Netherlands, provisioning for losses is made in accordance with International Accounting Standards (IAS 39), i.e. on an incurred losses basis, which does not take into account expected losses on performing or restructured loans. Under such a framework, there is a risk that provisions are insufficient. The DNB gathers detailed data to monitor the structure and quality of mortgage portfolios, but there is scope for further improvement. Like in most OECD countries, the DNB could develop an asset classification system under which banks have to report the quality of their loans and advances using a common regulatory scale (based on number of days that loans are overdue). Accordingly, the regulator could fix minimum levels for specific or general provisions for loans and advances. The DNB could require banks to write off non-performing loans after a specified period and collect comprehensive information on the degree to which Dutch banks have written off real estate portfolios.

Banks' exposure to the property market is extensive. The SNS Reaal bank-insurer was nationalised in early 2013 due to the high losses of SNS Bank linked to commercial real estate. The overall bank exposure to the domestic and foreign commercial property market is respectively almost EUR 80 billion and EUR 20 billion (in total around 15\% of GDP or 4\% of banks' total assets). The authorities have launched an indepth asset quality review of risks attached to commercial property loans. The aim is to ensure a realistic valuation of collateral in banks' books, greater scrutiny of banks' property models and higher provisions (DNB, 2013b). These are welcome steps.

Banks' mortgage portfolios should receive the same degree of scrutiny as their commercial business. Regulatory authorities should continue to request banks to hold sufficient capital for possible losses stemming from rising unemployment, the high share of households with negative home equity, large sensitivity to interest rate shocks and low mortgage amortisation. New international accounting standards (IFRS 9) are not yet enforced, but banks may also choose to apply them as of now, notably the new impairment methodology based on the expected credit loss model. For instance, Danish banks have recently been asked to boost provisions for borrowers who are unable to start amortising their mortgages. 


\section{Reducing the bank dependency on wholesale funding}

To progressively shift banks' funding model towards more stable sources, several policies could be considered. Deferred-amortisation loans could be systematically linked to a bank account, but such a measure would need to be implemented progressively to prevent liquidity problems in insurance companies when households' stable assets are withdrawn. The government could consider raising the current tax on liabilities other than equity and deposits (KPMG, 2012). The small difference between the tax rates for liabilities for less and more than one year, respectively $0.044 \%$ and $0.022 \%$, could also be increased. Continuing the restructuring of banks' balance sheets by rationalising non-core activities would also help to reduce their dependence on wholesale funding. Total loans granted to Dutch households and non-financial corporations represent only half of banks' total assets, against $80 \%$ in the mid-1990s.

The government is considering setting up a National Mortgage Institute, which would securitise part of the mortgage debt and sell it to international and national institutional investors, such as Dutch pension funds. The objective is to increase banks' funding stability, lower banks' costs and pass on this advantage to new borrowers and borrowers who renegotiate their interest rate. The government would retain the credit risk as only mortgages covered by the public National Mortgage Guarantee (NHG) guarantee scheme (which insures against residual liabilities left after a sale of a property) would be eligible. It is necessary to ensure that government's exposure to the NHG scheme (currently at $25 \%$ of GDP) does not increase further and that pension funds' decisions remain prudent in terms of return, risk and investment diversification, including internationally (total pension assets are $165 \%$ of GDP and $15 \%$ of them are already invested in the Netherlands).

\section{Reducing risks to the banking sector by supporting household deleveraging}

Mortgage loan delinquencies remain low, but low amortisation, rising joblessness, high sensitivity to changes in interest rates and falling house prices increase vulnerabilities as well as risks of social hardship. As discussed below, a key issue in this context for the Netherlands is to ensure a gradual deleveraging of households. Banks could be less willing to refinance borrowers with negative home equity who cannot repay their loan at maturity. Numerous repossessions could be socially and politically difficult to enforce in case of defaults, and would deepen banks' losses if large forced sales destabilise house prices.

\section{Reducing the risk of future household over-indebtedness}

Generous tax incentives for homeownership in the OECD (Figure 18) contributed to a simultaneous rise of house prices and household indebtedness in the run-up to the global crisis, magnifying the impact of lower interest rates and expectations of higher incomes and house prices. In fact, the rise in household indebtedness was much steeper than the rise in house prices in international comparison (Figure 19). Until recently, mortgage interest payments for primary residences were fully deductible from taxable income, up to a maximum period of 30 years. Deductions were not constrained in terms of amount and were worth the most for earners subject to the top marginal tax rate. Imputed rents were taxed, but at a maximum rate of only $0.6 \%$ (now at $0.7 \%$ ) of the economic value for dwellings worth less than EUR 1 million (Andrews et al., 2011; Vandevyvere and Zenthöfer, 2012; OECD, 2010, 2012). These tax incentives fostered homeownership and indebtedness, including by encouraging deferred repayment of principal to enhance the tax benefit. In turn, tax breaks tended to be capitalised in house prices (Andrews et al., 2011). With rising values of collateral and growing public guarantees (NGH scheme), banks relaxed down-payment constraints and accepted ever higher LTV ratios, which for new mortgages reached 120\% in 2010 (IMF, 2011a). 
Figure 18. Tax relief on debt financing cost of homeownership

Difference between the market interest rate and the after-tax debt financing cost of housing, $2009^{1}$

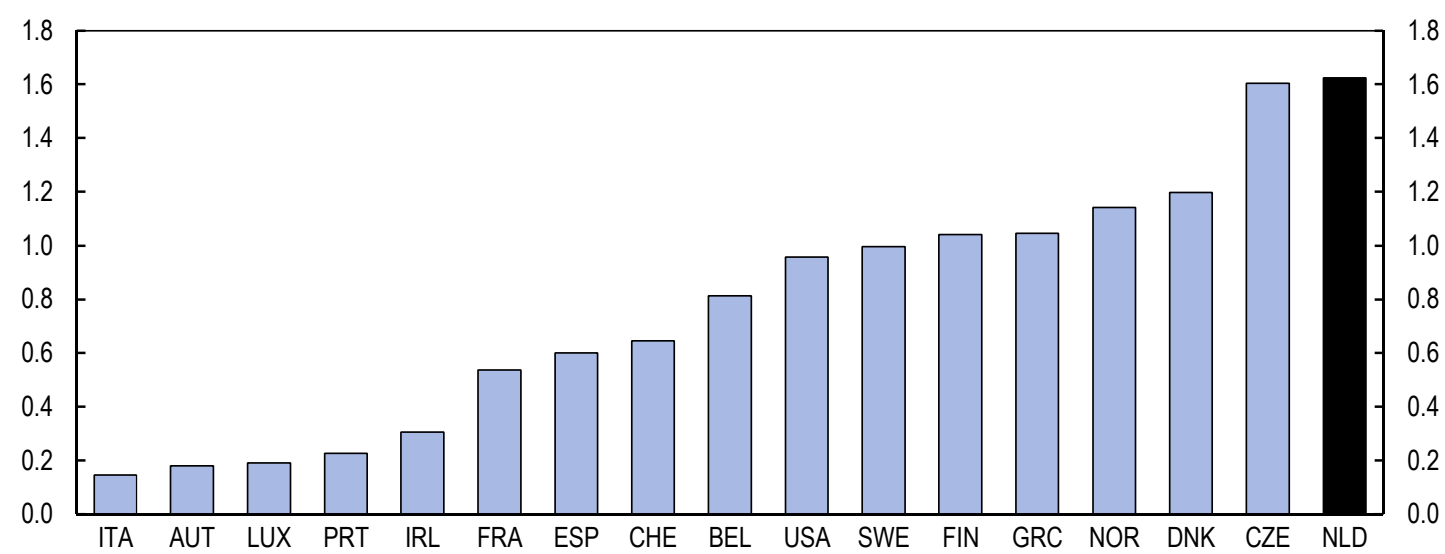

1. This indicator takes into account if interest payments on mortgage debt are deductible from taxable income and if there are any limits on the allowed period of deduction or the deductible amount, and if tax credits for loans are available. For countries that have no tax relief on debt financing costs, this indicator takes the value of zero.

Source: D. Andrews, A. Caldera Sánchez and A.. Johansson (2011), "Housing Markets and Structural Policies in OECD Countries", OECD Economics Department Working Papers, No. 836.

Figure 19. Feedback effects between house prices and household debt are strong

Change from 2000 to 2007

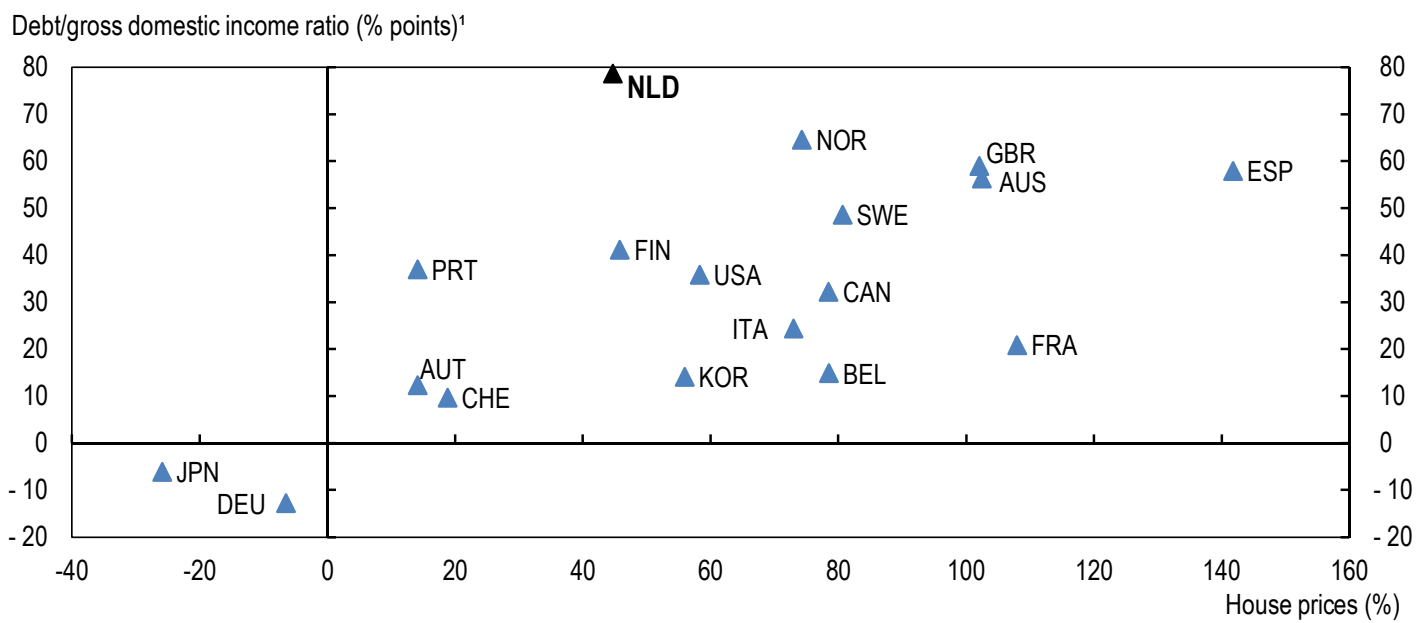

1. 2001-07 for Japan, 2002-07 for Korea.

Source: OECD (2014), OECD Housing Prices Database, Economics Department, February and OECD National Accounts Statistics (database), February.

Several reforms have striven to control household leverage and make it more sustainable. In 2001, mortgage interest relief was restricted to primary residences, the maximum period of deductibility reduced to 30 years and the marginal tax benefit cut to $52 \%$. In 2004, tax deductibility of mortgage interest in case of relocation was limited to the difference between the value of the new mortgage and capital gains on the previous dwelling. Since 2007, capital accumulation on bank savings accounts has been encouraged through tax exemptions, which had been allowed only for insurance products before. In 2011, the mortgage 
code of conduct used for self-regulation among mortgage originators recommended to cap the LTV ratio at $106 \%$ and underwrite interest-only mortgages up to a maximum of $50 \%$ of the property value.

More recently, additional reforms have been implemented and are steps in the right direction. Since 2013, interest deductibility has been restricted to new mortgages with regular repayment of the principal within 30 years, which is a commendable measure. However, new borrowers can take a second interestonly loan to redeem up to $50 \%$ of the first loan (Van Leeuwen, 2013). The tax treatment of mortgage interest has been made less generous for both new and existing mortgages, but with a very gradual lowering of the tax relief from $52 \%$ to $38 \%$ between 2014 and 2042 . The maximum value of a mortgage eligible for the NHG guarantee scheme was reduced from EUR 350000 in 2009 to EUR 290000 in July 2013 and should drop to EUR 260000 from July 2014. Also, a one-off fee borrowers pay for the scheme has been increased from $0.85 \%$ to $1 \%$ (previously raised from $0.7 \%$ ). Finally, the maximum LTV ratio for new mortgages will be cut in steps from $106 \%$ in 2012 to $100 \%$ in 2018.

Reforms need to be deepened as soon as the housing market recovery is sustainable. To improve tax neutrality, the taxation of housing should be at a level consistent with the taxation of financial incomes (Andrews et al., 2011). The taxation of housing corresponds to the first-best policy as mortgage interest deductibility is allowed and imputed rents are taxed, but the former should be lowered more quickly and the latter taxed more. This would diminish the bias in favour of owning a home instead of renting it, and reduce the bias in favour of housing investment compared to the allocation of savings to other asset classes. The fee to benefit from the NHG scheme should be adjusted for risk, by for instance linking it to the size of the LTV ratio. Continuing to cap the LTV ratio and lowering it significantly below $100 \%$ would limit the interest burden, decrease the incidence of negative home equity and reduce default rates. The latter noticeably increase for LTVs above 80\% in the US (Qi and Yang, 2009; White and Bauguess, 2013). Lower LTVs would also free up banks' capital and decrease their refinancing risks (SER, 2013). Alternatively, instead of introducing a cap, lower LTV ratios could be incentivised by setting a floor for risk weights (FSB, 2011a).

The Dutch rental sector is heavily skewed towards the public rental sector and developing the private rental market would give time to households to accumulate an adequate mortgage deposit. Recent reforms have initiated a welcome differentiation of rents depending on income in social housing (representing about $35 \%$ of the housing stock). They should be continued and would need to be coupled with tighter income conditions for eligibility to ensure that social housing associations focus on providing affordable housing only for low-income households. In parallel, as assessed in a chapter on the housing market in the 2010 Survey (OECD, 2010; Høj, 2011b), it is necessary to promote the development of the private rental market by progressively liberalising rents to create an alternative to homeownership and social housing. Ensuring a stronger role for a property's value in setting maximum rents, as currently planned, would be a step in the right direction. Additional far-reaching measures would include fully liberalising rents in new constructions and deregulating rents for new contracts in existing dwellings.

\section{Facilitating debt amortisation of existing loans}

Reforms need to be broadened to reduce the stock of household debt in the medium term. Empirical evidence suggests that actual household debt as a share of GDP exceeds a sustainable ratio by almost 40 percentage points (European Commission, 2013). Debt will become more sustainable if house prices start to rise, but this seems unlikely soon (Figure 7). Time series regressions suggest diminishing but still existing overvaluation of house prices (IMF, 2013b, c). An eventual normalisation of the ECB policy rate and a projected long-term decline of total population in the absence of net migration (Johanson et al., 2013) would further weigh on house prices, though low housing supply and diminishing household size should provide some offset. 
Low potential growth, estimated by the European Commission and the OECD to be respectively around $0.5 \%$ and $1 \%$ in 2014, suggests that income increases are unlikely to be sufficient to yield necessary deleveraging. Alternatively, deleveraging can occur through lower growth of new loans, increased debt repayments or debt restructuring. Regulatory authorities could prompt lenders to contact their borrowers holding interest-only mortgages and inform them about needed repayment of the loan at the end of the term as, for instance, in the United Kingdom (FCA, 2013). Well capitalised banks could be less willing to refinance borrowers with negative home equity who cannot repay their loan at maturity.

A more fundamental way to reduce household debt would be to more strongly incentivise amortising behaviour for existing mortgages once the housing market has recovered durably. In particular, this could be achieved by accelerating the reduction of the mortgage interest relief. Also, redemptions of loans with deferred amortisation should be closely monitored to prevent practices of "evergreening" by banks. Higher amortisation of existing mortgages would reduce banks' exposure to liquidity and solvency risks linked to the housing market, and improve consumer protection for vulnerable households. Concerns about the accumulation of illiquid and/or excessive net wealth by seniors are overstated. Home equity could be extracted by developing reverse mortgages (repaid from equity through the sale of the house) or home equity loans (repaid in regular instalments). In particular, there is an important potential to introduce reverse mortgages in the Netherlands (Dillingh et al., 2013), but it is necessary to ensure that underwriting standards for such loans are well defined and robust.

For borrowers who would be unable to start paying the principal when they refinance their debt with a new loan, banks could propose another mortgage with regular amortisation and longer maturity, or otherwise it would be advisable that they raise their capital for expected losses or boost their loan loss provisions if borrowers are only able to pay the interest. Denmark has recently decided that debtors who have difficulties to begin amortising their mortgage (interest-only for ten years) with a LTV ratio of over $80 \%$ can convert it into a 30 -year loan with amortisation; otherwise banks have to build higher provisions for borrowers only able to pay the interest on a new loan (OECD, 2014a).

Details remain unknown, but the government intends to open a debate on whether to allow borrowers to use their pension capital to redeem their mortgage debt (Government of the Netherlands, 2013b). While high levels of pension adequacy in the Netherlands (OECD, 2013b) could make this idea appealing at first sight, related challenges and risks are sizeable. These include the need to make a complete overhaul of the second pension pillar (which ensures risk sharing as there are no individual pension accounts), the risk of using assets without a corresponding reduction in liabilities (which would threaten the solvency of pension funds), the danger of a premature consumption of wealth if additional loans are contracted (which would ultimately lead to pressures on the government to improve pension adequacy) and the threat of undermining the stability of pension funds by assigning them duties going beyond their primary role. Instead of drawing on pension assets, the government could consider socialising losses of mortgage delinquencies or resolving failed banks.

\section{Reviewing personal insolvency}

Household insolvencies have experienced a significant increase between 2009 and 2011. Yet, the number of insolvencies per number of households is similar to countries with creditor-friendly regimes (France) and much lower than in debtor-friendly regimes (United Kingdom and United States) (Liu and Rosenberg, 2013). Given the sharp decline in house prices and the high debt burden of Dutch households, one could expect a higher number of insolvencies, suggesting that the Dutch personal insolvency regime is likely to be closer to creditor-friendly regimes rather than debtor-friendly ones.

Dutch mortgages are full recourse, with the creditor having recourse to other assets and even future income of the debtor (Van Leeuwen and Bokeloh, 2012). Since the new legislation in 2008, debtors are 
freed from their commitments if they cannot make significant contributions, rendering the system more debtor-friendly (London Economics, 2012). The Dutch framework for personal insolvency allows for out-of-court mediation and a fresh start after a period of 3 years (maximum 5 years), following the debt rescheduling regime ("schone lei"). In comparison, the rescheduling regime can go from one year in the United Kingdom to around eight years in France; it has recently been shortened from 12 to 3 years in Ireland and from 6 to 3 years in Germany (if $25 \%$ of the debt is repaid). Based on these numbers, the Dutch regime appears relatively standard. Nevertheless, due to different judicial practices, these numbers do not allow proper understanding of how the rescheduling regime is enforced by courts. It is also uncertain to what extent banks allow informal mortgage debt rescheduling.

Under creditor-friendly insolvency and foreclosure laws, widespread repossessions could be socially and politically difficult to enforce in case of defaults, and would deepen banks' losses if large forced sales destabilise house prices. On the other hand, a new law is being prepared to cancel partially or fully "unexpected" debts linked to inheritance, which could put high risks on creditors. This is why it is important to balance creditor and debtor rights to ease loan restructuring and ensure household deleveraging in an orderly way, as well as protect some borrowers from extreme financial distress. In the case of the Netherlands, increasing the possibility of rescheduling for overindebted households, speeding it up and allowing greater debt discharge that takes into account borrower reimbursement capacity would be useful to facilitate household deleveraging. Also, lender-friendly foreclosure laws can weaken underwriting standards and have been found to be associated with a higher incidence of subprime originations in the United States (Curtis, 2013).

\section{Enhancing supervision and consumer protection within the framework of the banking union}

On behalf of the Dutch parliament, the De Wit (2010) and Scheltema (2010) commissions have undertaken an evaluation of causes and failures that led to the crisis. Based on their assessments, the regulator did not adequately recognise the main systemic vulnerabilities, such as large cross-border exposures, reliance on wholesale funding, increased leverage and sizeable portfolios of structured securities. Despite showing a high degree of compliance with banking regulatory standards, the supervisory approach largely relied on moral suasion similar to other regulators, which became less effective as financial institutions became larger and more complex (IMF, 2011b).

When a single European supervisory mechanism is effectively established, national authorities in cooperation with the ECB will retain responsibilities in: $i$ ) day-to-day assessment of credit institutions and related on-site verification; ii) consumer protection; iii) macro-prudential policies that include countercyclical buffers and other measures to address systemic risks; and $i v$ ) early intervention and precautionary powers.

\section{Limiting supervisory liability and making the supervisory approach more intrusive}

The DNB new supervisory approach seeks to make supervision more intrusive. The DNB has set up a separate new division with a stronger role for experts, a department for internal risk management and a department responsible for intervention policy to safeguard timely responsiveness. This is accompanied by increased staff resources and changes in the organisational set-up of the DNB. The liability of the supervisors has been limited, which is crucial as 91 enforcement actions were contested in courts and one action was overruled between 2006 and 2010 (Cihák, et al. 2012). In contrast, in most OECD countries courts are never or rarely involved, exceptions being Austria and Italy with respectively 91 and 10 contestations.

The Netherlands has implemented the Financial Stability Board (FSB) Principles for sound compensation practices (FSB, 2011b). The regulator has replaced senior management in the nationalised 
institutions (ABN AMRO and SNS Reaal). A law that bans variable remuneration for all management board members of financial institutions that receive state aid came into force in June 2012 including a freeze of the fixed salary. A fit and proper test for managers of financial institutions has been improved. However, these steps may not be ambitious enough. Compensation packages should be supervised directly by the regulator as recommended by the Financial Stability Board (FSB, 2011b).

Macroprudential oversight is being improved by a financial stability committee in charge of recommendations on macroprudential policies (Box 1.1). The establishment of a committee for co-operation on macroprudential policy is welcome. However, the committee plays only an advisory role, and the reform does not change existing competencies. It is up to the individual authorities to consider and act on recommendations from the committee. To increase the effectiveness of the financial stability committee, its enforcement powers and accountability should be improved. To be able to react to emerging economic or financial conditions, the regulator should have the power to make use of macroprudential instruments such as the LTV ratio.

\section{Box 1. The framework of financial supervision}

Financial supervision is organised under the "twin peaks" supervisory structure. This approach to financial regulation separates regulatory functions by objectives allowing each regulator to focus on a single core mandate. In the Netherlands it involves two main institutions, the De Nederlandsche Bank (DNB) and the Authority for Financial Markets (AFM):

- The DNB is the single prudential supervisor for all financial institutions. Micro and macroprudential oversight is concentrated in the DNB, so it has the ability to take a systemic view.

- The AFM is the supervisor responsible for conduct-of-business supervision, including supervision of security market activities, with a strong focus on market behaviour and consumer protection.

The Ministry of Finance is responsible for financial sector legislation and makes the ultimate decision to provide public support to banks in crisis.

To strengthen macroprudential oversight, a financial stability committee consisting of members of the Ministry of Finance, the DNB and the AFM was set up in January 2013 responsible for macroprudential supervision. The mandate of the Committee is to: $i$ ) facilitate the exchange of information and the analysis of risks; ii) align the policies of the participating authorities; iii) take stock of desirable improvements in macroprudential instruments; and iv) co-ordinate the follow-up to recommendations of the European Systemic Risk Board.

\section{Improving cross-border arrangements}

Another reason for the problems associated with banks' cross-border exposure during the 2008-09 crisis was that regulation did not keep up with the expansion of Dutch banks abroad. The collapse of Fortis highlighted the need for stronger cooperation between different national regulators and for a harmonisation of bank bankruptcy laws across countries. It also revealed diverging views of Belgian and Dutch regulators over the issue of who should be the main supervisor for the Belgian-Dutch company. Because the company's headquarters were located in Belgium, the Belgian regulator was the main supervisor of the activities of the group, although, after acquiring ABN AMRO, the size and the importance of business units located in the Netherlands increased considerably (Marinc and Vlahu, 2011). While issues related to cross-border supervision will be resolved by the European single supervisory mechanism, there are still no effective international crisis management and resolution tools (OECD, 2012, 2014b).

Today, international exposures of ING account for most of the cross-border activities. There have been many efforts to improve cross-border banking regulation. The DNB has started to coordinate with other supervisory authorities through so-called supervisory colleges. Within these supervisory colleges, the DNB has established a separate Crisis Management Group (CMG), which includes the relevant 
supervisors, central banks and ministries of finance. Resolution plans of banks are shared and discussed with the members of the CMG. Further arrangements may need to be made with financial supervisors in countries hosting subsidiaries of Dutch banks. Legislation giving powers to the DNB to request information on foreign subsidiaries of Dutch banks is discussed, but should be passed as soon as possible.

\section{Strengthening consumer protection}

The responsibility for consumer protection in the area of financial products lies with the Authority for Financial Markets (AFM). International experience shows that lenient lending practices, such as interest-only mortgages and mortgages with high loan-to-value ratios, contributed to the subprime crisis (Demyanyk and Van Hemert, 2011) and had been responsible for bank failures during the Great Depression in the 1930s (Campbell et al. 2011). The ubiquitous nature of such practices in the Netherlands suggests that consumer protection needs to be strengthened through more intrusive regulation of mortgage products.

Better regulation is particularly important because mortgage products are key financial decisions for most households during their lifetime. Financial literacy is another element of consumer protection, which can complement but not be a substitute for it (OECD, 2009). There is a general agreement that it is essential for good financial decision-making and its lack could have been one of the reasons of the financial crisis (OECD, 2009; Lusardi and Mitchell, 2011). Despite its importance, financial literacy is poor in OECD countries, including in the Netherlands where $55 \%$ of people are not able to answer elementary questions about compound interest rates, inflation and diversification (see Box 1.2).

\section{Box 2. Financial literacy in the Netherlands}

To measure consumer literacy, Lusardi and Mitchell (2011) designed a set of the following three elementary questions that were piloted in national surveys:

- Suppose you had USD 100 in a savings account and the interest rate was $2 \%$ per year. After five years, how much do you think you would have in the account if you left the money to grow?

- More than USD102; Exactly USD102; Less than USD102; Do not know; Refuse to answer

- Imagine that the interest rate on your savings account was $1 \%$ per year and inflation was $2 \%$ per year. After 1 year, how much would you be able to buy with the money in this account?

- More than today; Exactly the same; Less than today; Do not know; Refuse to answer

- $\quad$ Please tell me whether this statement is true or false. "Buying a single company's stock usually provides a safer return than a stock mutual fund."

- True; False; Do not know; Refuse to answer

In Netherlands, only $45 \%$ of respondents succeeded in answering all three financial literacy questions correctly (Lusardi, 2013). It should be noted that this rate is rather high in international comparison (the corresponding rates are $53 \%, 27 \%$ and $30 \%$ in Germany, Japan and the United States). The above questions are very simple and their knowledge is not even nearly sufficient for decision making in the context of sophisticated and complex financial products. Van Rooij et al. (2012) show that only a tiny fraction of respondents (5\%) are able to answer 11 more advanced literacy questions correctly. These are important findings as one cannot assume that consumers are knowledgeable and well-informed about their financial choice.

References: A. Lusardi (2013), Financial Literacy Around the World (FLAT World), FINRA Investor Education Foundation; A. Lusardi and O. Mitchell (2011), "Financial Literacy around the World: An Overview", Journal of Pension Economics and Finance, Vol. 10, No. 4; M.C. van Rooij, A. Lusardi and R.J. Alessie (2012), "Financial Literacy, Retirement Planning and Household Wealth", Economic Journal, Vol. 122, No. 560. 
Improving financial literacy would be beneficial, but would also be costly and rather ineffective. Consumers do not appear to be interested even in free financial literacy courses, due to high costs related to time and effort, and in any case financial education does not lead to better financial decisions (Choi et al, 2011; Willis, 2011; Campbell et al. 2011). Interestingly, 60\% of Dutch consumers trust the advice of financial institutions, despite potential conflicts of interest (European Commission, 2010). The AFM should make a comprehensive survey of financial products to understand their risks and be vigilant about the appearance of new financial products that might be sub-optimal for households and for financial stability.

\section{Improving the resolution framework}

\section{Ensuring a better protection of taxpayers and depositors}

A necessary reform to reinforce the effectiveness of supervision is to design an orderly resolution mechanism. This is a key element on the international agenda of financial market reform (FSB, 2011b; Zhou et al., 2012), which should help restructure banks in difficulty. In 2012, the Netherlands introduced a special resolution regime for banks - the Intervention Act - which provided the DNB and the Ministry of Finance with new resolution powers that can be exercised without shareholder consent. DNB has to submit a transfer plan to the court and, once approved, the court appoints a person to execute the plan. If the failure of a bank poses a serious and immediate danger to the stability of the financial system, the Minister of Finance has the power to intervene without court approval (FSB, 2013). New resolution powers of the DNB and the Ministry of Finance include: i) removal and appointment of senior management; ii) appointment of a "silent" administrator; iii) transfer of assets and liabilities; $i v$ ) establishment and operation of a bridge bank; $v$ ) transfer of assets to the asset management company; and vi) possibility to expropriate equity and subordinated debt.

The powers of the Intervention Act were tested for the first time to bail-in junior debt and shareholders when SNS Reaal was nationalised in February 2013. Currently, the government is working on the creation of a state-owned bad bank to transfer the property portfolio of SNS Reaal. The new framework reduces moral hazard and achieves a fairer burden sharing of bank bailouts. The Intervention Act could also be improved by introducing criteria and early-warning mechanisms as to when a resolution procedure should be launched. Similarly to the United States, the regulator could be allowed to trigger resolution procedures as soon as the capital is below a certain threshold, while still being positive, so as to limit the potential cost for the taxpayer. Asset encumbrance may also raise further the cost of bank resolution that is undertaken too late (Hardy, 2013). The threshold should be based on unweighted capital to avoid banks' manipulation of the risk weights. It is also important that the regulator specifies ex ante the measures to be taken in the event of a resolution procedure and at which stage they would need to be enforced so as to reduce the risk of regulatory forbearance.

Further progress is expected with the Bank Recovery and Resolution Directive (BRRD) at the EU level, which is set to harmonise rules for recapitalisation and orderly resolution of banks by 1 January 2015. From 2016, total losses of private investors will have to amount to at least $8 \%$ of the bank's balance sheet before drawing on a bank-financed ex ante domestic resolution fund (expected to reach the level of $1 \%$ of domestic covered deposits by 2025) and public funding. A recently agreed European single resolution fund of EUR 55 billion, to be built up over the next eight years, could also be used in periods of acute stress. The new framework should more easily allow the bail-in of senior bondholders, which was ruled out in the case of SNS Reaal, resulting in a higher cost for the taxpayer.

To buttress the protection of the taxpayer, it is important that banks maintain a sufficient level of debt that can be used for bail-in. Currently, many banks are increasing their secured funding as a way to limit their funding costs. Secured funding, such as covered bonds, grants creditors preferential claims that are 
guaranteed by collateral and are not eligible to bail-in. This leads to asset encumbrance and entails the risk of higher potential losses to unsecured creditors, including uninsured depositors (and potentially the taxpayer for the part of deposits insured by the government). At around $15 \%$, average asset encumbrance of Dutch banks is lower than the European average of $25 \%$, partly owing to prudential limits set by the DNB for the volume of covered bonds issued (DNB, 2013c). The monitoring of risks linked to asset encumbrance needs to be continued. To allow markets to price adequately unsecured debt and banks to get sufficient amount of such debt, the regulator should ensure that banks improve the disclosure of encumbered assets, as in Sweden (BIS, 2013b). In addition, to balance the risk-burden between secured and unsecured creditors, capital requirements could be linked to the level of asset encumbrance (BIS, 2013b).

Depositor preference provides guarantees for depositors in comparison with other unsecured creditors. According to the BRRD, deposits of natural persons and SMEs above EUR 100000 will benefit from a preferential treatment as they will not suffer from losses before all other unsecured creditors' claims (shareholders, junior and senior bondholders, and depositors from large corporations) are absorbed. This should limit the potential cost for the government at the same time, which ultimately guarantees deposits covered by the national deposit guarantee scheme (DGS), i.e. all deposits below the ceiling of EUR 100000 per bank. A bankruptcy of SNS Reaal would have activated the DGS to pay out depositors and would have induced large claims on other Dutch banks (since the current DGS is funded ex post by banks) and might have triggered a bank run (since there is no depositor preference for uninsured depositors). The Dutch authorities plan to introduce a DGS funded ex ante by the banking sector. Such arrangement was delayed, but it is set to be introduced in the Netherlands in 2015. The introduction of both depositor preference and of an ex ante DGS will be an important improvement of the current resolution framework.

\section{Effectively dealing with large banks}

The Intervention Act equips the DNB and the Ministry of Finance with stronger intervention powers to address a financial turmoil, but their effective use could be uncertain for large banks. These often have a complex and opaque legal structure that consists of myriads of legal entities, set up in part to exploit regulatory and tax loopholes. Moreover, bank-insurer groups could have a "double leverage", as in the case of SNS Reaal, resulting in less equity at the conglomerate level than reported by each arm, which can hamper restructuring (Ministry of Finance, 2013b). Faced with such a legal structure, attracting potential buyers is more difficult. Also, the authorities may not be able to distinguish systemically important parts and could be forced to rescue the whole conglomerate due to fears of contagion. In doing so, they may reinforce the "too-big-to-fail" problem and increase moral hazard. To resolve this issue, banks should be required to draw up recovery and resolution plans ("living wills"), as has been proposed by the Dutch government in its "Banking vision paper" (Government of the Netherlands, 2013a). In these plans, banks should develop scenarios under which certain, less important, parts can be sold, or put into liquidation. The systemically important parts may then be rescued (Avgouleas et al., 2013).

A credible "living will" requires a legal structure that is straightforward and that allows identifying and separating systemically important bank parts. Hence, the development of "living wills" should lead to a simplification of the legal structure. The supervisors should have the power to enforce such restructuring solely to improve resolution, as it is the case in Spain, Switzerland, the United Kingdom and the United States (FSB, 2011b). Moreover, banks should disclose the number of subsidiaries and branches abroad, including their presence in offshore financial centres (as it has recently been introduced in France, the United Kingdom and the United States).

Another option to reduce risks posed by large banks to the taxpayer is to restrict the business scope by separating their investment divisions, or at least proprietary trading as this is being implemented in some 
OECD countries (France, the United Kingdom and the United States), discussed at the EU level, and recommended by the Commission on the Structure of Dutch Banks (2013). The DNB (2012) argues that such separation of financial businesses is not necessary for Dutch financial institutions, as investment bank activities of Dutch banks are relatively small. Indeed, the ratio of available-for-sale assets to total assets of Dutch banks is low in international comparison and has further declined after the crisis (Figure 20). Nevertheless, a separation of such activities could be important for resolution purposes to ring-fence systemically important activities (such as market making) from proprietary trading that can be liquidated in times of financial distress.

\section{Figure 20. Available-for-sale financial assets}

Per cent of total assets
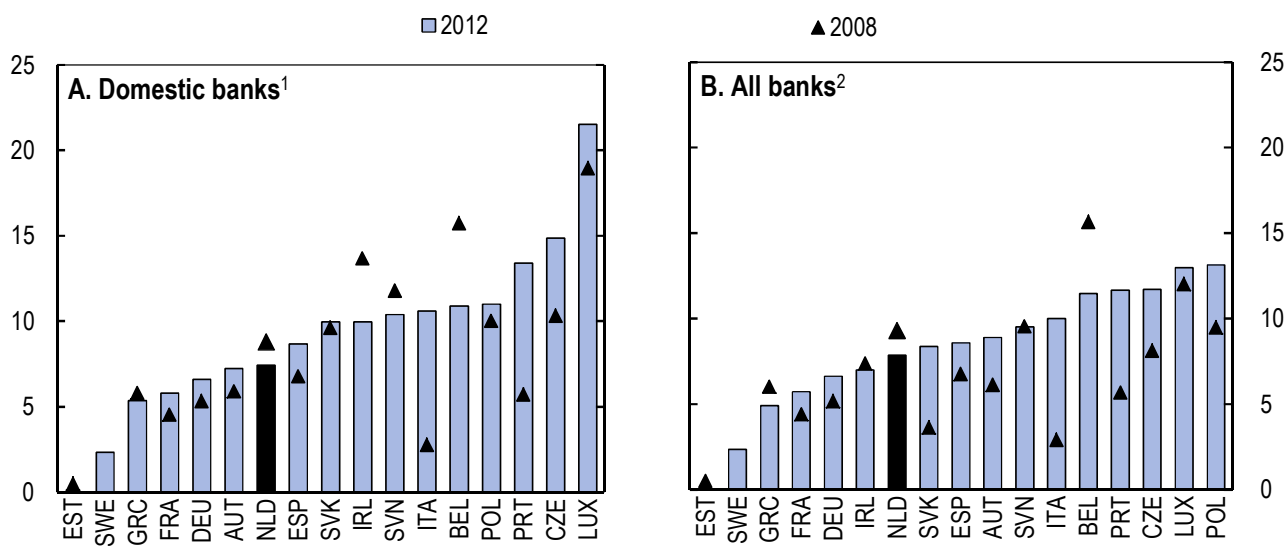

1. Domestic banking groups and stand-alone banks.

2. Domestic banking groups and stand-alone banks as well as foreign controlled subsidiaries and branches.

Source: ECB (2014), "Consolidated Banking Data", Statistical Data Warehouse, European Central Bank, March.

\section{Box 3. Main policy recommendations to increase the resilience of the banking sector}

\section{Bolstering banks' financial buffers}

- Review the mortgage loan portfolio and continue to request banks to hold sufficient capital for expected losses owing to rising unemployment, the high share of households in negative home equity, exposure to interest rate changes and low amortisation behaviour.

- $\quad$ Adopt a uniform definition of a non-performing loan across banks.

- Encourage banks to further increase their capital adequacy ratios by issuing equity and retaining earnings through lower dividend payments and reduction of costs.

- $\quad$ Phase in maximum Basel III standards on systemically important bank capital buffers and aim for strong leverage ratios for systemically important banks.

\section{Tackling household mortgage debt overhang}

- Once the housing market starts to recover durably, increase incentives for amortisation of mortgages by accelerating the reduction of mortgage interest relief and work towards ensuring neutrality between the taxation of housing and the taxation of financial incomes. Lower the maximum loan-to-value ratio significantly below $100 \%$. 
- Promote the development of home equity loans and reverse mortgages, and consider gradually linking mortgages with deferred amortisation to principal accumulation on a bank account.

- For households unable to start paying the principal when they refinance their debt with a new loan, encourage banks to grant another mortgage with longer maturity and regular redemption. Require banks to increase provisions for distressed borrowers only able to pay the interest.

- $\quad$ To ease loan restructuring, reform personal insolvency law by balancing creditor and borrower rights.

- Continue to improve targeting of social housing to low-income households through means tested rent increases and ease rent regulations in the private rental market by increasing the role of property's value in setting maximum rents, freeing rents in new constructions and deregulating rents for new contracts in existing dwellings.

\section{Improving the resolution of banks}

- To go beyond bail-in regulations to reduce potential costs of resolutions for taxpayers and depositors, link capital requirements to the level of asset encumbrance, and build a domestic resolution fund and a deposit guarantee scheme both funded ex ante by banks as foreseen at the euro area level to create a banking union.

- Require large banks to draw up recovery and resolution plans ("living wills"). The De Nederlandsche Bank (DNB) should have the power to enforce a simplified legal structure and require banks to provide information about their subsidiaries and branches abroad, including in offshore financial centres. 


\section{Bibliography}

Admati, A., P. DeMarzo, M. Hellwig and P. Pfleiderer (2010), "Fallacies, Irrelevant Facts, and Myths in the Discussion of Capital Regulation: Why Bank Equity is not Expensive", Stanford GSB Research Paper, No. 2063, Stanford University.

Aghion, P., P. Howitt and D. Mayer-Foulkes (2005), "The Effect of Financial Development on Convergence: Theory and Evidence.” Quarterly Journal of Economics, Vol. 120, Oxford University Press.

Alloway, T. ( 2011), "How to Tinker with Bank Risk-Weighting”, FT Alphaville, 08 June, The Financial Times Limited.

Andrews, D., A. Caldera-Sánchez and A.. Johansson (2011), "Housing Markets and Structural Policies in OECD Countries", OECD Economics Department Working Papers, No. 836, OECD Publishing.

Arcand, J., E. Berkes and U. Panizza (2012), “Too Much Finance?”, IMF Working Paper, No. 12/161, International Monetary Fund.

Avgouleas, E., C. Goodhart and D. Schoenmaker (2013), "Bank Resolution Plans as a Catalyst for Global Financial Reform”, Journal of Financial Stability, No. 9, Vol. 2, Elsevier.

Baba, N., R. McCauley and S. Ramaswamy (2009), "US Dollar Money Market Funds and Non-US Banks", BIS Quarterly Review, March, Bank for International Settlements.

Bank of England (2013), “The Financial Policy Committee's Powers to Supplement Capital Requirements", A Draft Policy Statement.

Beck, T., B. Büyükkarabacak, F.K. Rioja and Neven T. Valev (2012), "Who Gets the Credit? And Does it Matter? Household vs. Firm Lending across Countries." B.E. Journal of Macroeconomics, Vol. 12, De Gruyter.

Berben, R., B. Bierut, W. van den End and J. Kakes (2010), "Macro-Effects of Higher Capital and Liquidity Requirements for Banks. Empirical Evidence for the Netherlands", DNB Occasional Study, No. 3, De Nederlandsche Bank.

Bijlsma, M. and J. Mocking (2014), “The Private Value of Too-Big-to-Fail Guarantees”, CPB Discussion Paper, No. 240, Centraal Planbureau.

BIS (2013a), "Analysis of Risk-weighted Assets for credit Risk in the Banking Book", Regulatory Consistency Assessment Programme, Basel Committee on Banking Supervision, Bank for International Settlements.

BIS (2013b), “Asset Encumbrance, Financial Reform and the Demand for Collateral Assets", CGFS

Papers, No. 49, Basel Committee on Banking Supervision, Bank for International Settlements.

BIS (2010), “An Assessment of the Long-Term Economic Impact of Stronger Capital and Liquidity Requirements", Basel Committee on Banking Supervision, Bank for International Settlements. 
Blundell-Wignall, A. and C. Roulet (2013), "Business Models of Banks, Leverage and the Distance-todefault", OECD Journal: Financial Market Trends, Vol. 2012/2, OECD Publishing.

Broos M., K. Carlier, J. Kakes and E. Klaaijsen (2012), "Shadow Banking: An Exploratory Study for the Netherlands”, DNB Occasional Studies, Vol. 10, No. 5, De Nederlandsche Bank.

Campbell, J., H. Jackson, B. Madrian and P. Tufano (2011), “Consumer Financial Protection”, Journal of Economic Perspectives, Vol. 25, No. 1, American Economic Association.

Chakraborty, I., I. Goldstein and A. MacKinlay (2013), "Do Asset Price Bubbles have Negative Real Effects?", http://dx.doi.org/10.2139/ssrn.2246214.

Chernenko, S. and A. Sunderam (2012), "The Quiet Run of 2011: Money Market Funds and the European Debt Crisis", Dice Centre Working Papers, No. 2012-4, Ohio State University.

Choi, J., D. Laibson and B. Madrian (2011), “\$100 Bills on the Sidewalk: Suboptimal Investment in 401(k) Plans", Review of Economics and Statistics, Vol. 93, No. 3, MIT Press Journals.

Cihák, M., A. Demirgüç-Kunt, M. Soledad Martínez Pería and A. Mohseni (2012), "Banking Regulation and Supervision around the World: Crisis Update", Policy Research Working Paper, No. 6286, World Bank.

Commission on the Structure of Dutch Banks (2013), "Towards a Serviceable and Stable Banking System", Report, June.

Curtis, Q. (2013), "State Foreclosure Laws and Mortgage Origination in the Subprime", Journal of Real Estate Finance and Economics, August, Springer.

De Wit Commission (2010), "Parlementair Onderzoek Financieel Stelsel” (Parlementary enquiry of the financial system).

Demyanyk, Y. and O. Van Hemert (2011), "Understanding the Subprime Mortgage Crisis", Review of Financial Studies, Vol. 24, No. 6, Oxford University Press.

Dillingh, R., H. Prast, M. Rossi and C. Brancati (2013), "The Psychology and Economics of Reverse Mortgage Attitudes: Evidence from the Netherlands", CERP Working Paper, No. 135/13, Center For Research on Pensions and Welfare Policies.

DNB (2014), "Banks Still Have a Long Way to Go to Meet the Basel III and CRD IV Requirements", Newsletter Banks, January, De Nederlandsche Bank.

DNB (2013a), Overview of Financial Stability in the Netherlands, Autumn, No. 18, De Nederlandsche Bank.

DNB (2013b), Annual Report 2012, De Nederlandsche Bank.

DNB (2013c), Overview of Financial Stability in the Netherlands, Spring, No. 17, De Nederlandsche Bank.

DNB (2012), Annual Report 2011, De Nederlandsche Bank. 
ECO/WKP(2014)52

DNB (2009), Overview of Financial Stability in the Netherlands, November, No. 10, De Nederlandsche Bank.

ECB (2013a), Banking Structures Report, November, European Central Bank.

ECB (2013b), Financial Stability Review, November, European Central Bank.

European Commission (2013), "Macroeconomic Imbalances. Netherlands 2013", European Economy Occasional Papers, No. 140.

European Commission (2010), Consumer Decision-Making in Retail Investment Services: A Behavioural Economics Perspective, Final Report.

FCA (2013), Dealing Fairly with Interest-only Mortgage Customers who Risk Being Unable to Repay their Loan, Finalised Guidance, Financial Conduct Authority.

Fitch Ratings (2013), “U.S. Money Fund Exposure and European Banks: Eurozone 'Core' Rises”, 26 November.

FSB (2013), Thematic Review on Resolution Regimes, Peer Review Report, Financial Stability Board.

FSB (2012), Global Shadow Banking Monitoring Report 2012, Financial Stability Board.

FSB (2011a), Thematic Review on Mortgage Underwriting and Origination Practices, Peer Review Report, Financial Stability Board.

FSB, (2011b), Key Attributes of Effective Resolution Regimes for Financial Institutions, Financial Stability Board.

Government of the Netherlands (2013a), "Banking vision paper: towards a robust, ethical and competitive banking sector".

Government of the Netherlands (2013b), "Wijzigingsvoorstellen Witteveen 2015”, Ministry of Finance, 18 December.

Haldane, A.G. (2011), “Capital Discipline”, Speech given at the American Economic Association, Denver, 9 January.

Hardy, D. (2013), "Bank Resolution Costs, Depositor Preference, and Asset Encumbrance", IMF Working Paper, No. WP/13/172, International Monetary Fund.

Høj, J. (2011a), "Making the Dutch Pension System Less Vulnerable to Financial Crises", OECD Economics Department Working Papers, No. 832, OECD Publishing.

Høj, J. (2011b), "Improving the Flexibility of the Dutch Housing Market to Enhance Labour Mobility", OECD Economics Department Working Papers, No. 833, OECD Publishing.

IMF (2013a), Fiscal Monitor - Taxing Times, October, International Monetary Fund.

IMF (2013b), 2013 Article IV Consultation - Netherlands, IMF Country Report No. 13/115, International Monetary Fund. 
IMF (2013c), Nordic Regional Report, IMF Country Report No. 13/274, International Monetary Fund.

IMF (2011a), 2011 Article IV Consultation - Netherlands, IMF Country Report No. 11/142, International Monetary Fund.

IMF (2011b), Kingdom of The Netherlands - Netherlands, IMF Financial System Stability Assessment, Country Report No. 11/144, International Monetary Fund.

Jansen, J., M. Bijlsma, M. Kruidhof and C. Pattipeilohy (2013), "Funding Problems in the Mortgage Market", DNB Occasional Studies, Vol. 11, No. 1, De Nederlandsche Bank.

Johanson, A., Y. Guillemette, F. Murtin, D. Turner, G. Nicoletti, C. de la Maisonneuve, P. Bagnoli, G. Bousquet and F. Spinelli (2013), "Long-Term Growth Scenarios", OECD Economics Department Working Papers, No. 1000, OECD Publishing.

KPMG (2012), Bank Levies - Comparison of Certain Jurisdictions, Edition IX, June.

Liu, Y. and C. Rosenberg (2013), "Dealing with Private Debt Distress in the Wake of the European Financial Crisis", IMF Working Paper, No. 13/44, International Monetary Fund.

London Economics (2012), Study on Means to Protect Consumers in Financial Difficulty: Personal Bankruptcy, Datio in Solutum of Mortgages, and Restrictions on Debt Collection Abusive Practices, Final Report.

Lusardi, A. and O. Mitchell (2011), "Financial Literacy around the World: An Overview", Journal of Pension Economics and Finance, Vol. 10, No. 4, Cambridge University Press.

Marinc, M. and R. Vlahu (2011), “The Economic Perspective of Bank Bankruptcy Law”, DNB Working Paper, No. 310, De Nederlandsche Bank.

Ministry of Finance (2013a), Draft Budgetary Plan, September.

Ministry of Finance (2013b), "Nationalisation of SNS Reaal", Letter of the Minister of Finance to the Chairman of the Second Chamber of Parliament of the States General, Financial Markets Directorate, FM/2013/211M.

OECD (2014a), OECD Economic Surveys: Denmark 2013, OECD Publishing.

OECD (2014b), OECD Economic Surveys: Euro Area 2014, forthcoming.

OECD (2013a), OECD Economic Outlook, No. 94, OECD Publishing.

OECD (2013b), Pensions at a Glance, OECD Publishing.

OECD (2012), OECD Economic Surveys: Euro Area 2012, OECD Publishing.

OECD (2010), OECD Economic Surveys: Netherlands 2010, OECD Publishing.

OECD (2009), Financial Literacy and Consumer Protection: Overlooked Aspects of the Crisis, OECD Recommendation on Good Practices on Financial Education and Awareness Relating to Credit. 
Qi, M. and X. Yang (2009), "Loss Given Default of High Loan-to-Value Residential Mortgages”, Journal of Banking \& Finance, Vol. 33, No. 5, Elsevier.

Ratnovski, L. (2013), “How Much Capital Should Banks Have?”, VOX, 28 July.

Scheltema Commission (2010), “Onderzoek DSB Bank” (Research on the DSB bank).

Schoenmaker, D. and D. Werkhoven (2013), "The Impact of Multinationals on the Size of the Banking System”, Kyklos, Vol. 66, No. 3, Wiley-Blackwell.

SER (2013), Dutch Economy in Calmer Waters, Social and Economic Council, May.

Sveriges Riksbank (2013), Financial Stability Report 2013, No. 2.

The Economist (2012), "Testing the Case for Bottom-Heavy Banks," 12 November.

Van Leeuwen, R. (2013), Dutch Mortgage Market - Additional Loan Facility, ABN AMRO.

Van Leeuwen, R. and P. Bokeloh (2012), Mortgage Market in the Netherlands, ABN AMRO.

Vandevyvere, W. and A. Zenthöfer (2012), The Housing Market in the Netherlands, Working Papers, No. 457, European Commission.

White, J. and S. Bauguess (2013), "Qualified Residential Mortgage: Background Data Analysis on Credit Risk Retention", U.S. Securities and Exchange Commission, White Paper, August.

Willis, L.E. (2011), “The Financial Education Fallacy”, American Economic Review, Vol. 101, No. 3, American Economic Association.

Zhou, J., V. Rutledge, W. Bossu, M. Dobler, N. Jassaud, and M. Moore (2012), "From Bail-out to Bail-in: Mandatory Debt Restructuring of Systemic Financial Institutions", IMF Staff Discussion Note, No. 12/03, International Monetary Fund. 
ECO/WKP(2014)52

\section{WORKING PAPERS}

The full series of Economics Department Working Papers can be consulted at www.oecd.org/eco/workingpapers

1155. US long term interest rates and capital flows to emerging economies (July 2014) by Eduardo Olaberria

1154. Productivity measurement with natural capital and bad outputs (July 2014) by Nicola Brandt, Paul Schreyer and Vera Zipperer

1153. Reducing income inequality and poverty and promoting social mobility in Korea (July 2014) by Randall S. Jones and Satoshi Urasawa

1152. Fostering a creative economy to drive Korean growth (July 2014) by Randall S. Jones and Myungkyoo Kim

1151. Economic uncertainties and their impact on activity in Greece compared with Ireland and Portugal

(July 2014) by Jan-David Schneider and Claude Giorno

1150. Workplace stress in the United States: issues and policies (July 2014) by Michael Darden

1149. Taxing the rent of non-renewable resource sectors: a theoretical note (July 2014) by Julien Daubanes and Saraly Andrade de Sá

1148. Health, work and working conditions: a review of the European economic literature (July 2014) by Thomas Barnay

1147 Making the best of new energy resources in the United States (July 2014) by Douglas Sutherland

1146. Improving well-being in the United States

(July 2014) by Aida Caldera Sánchez, Patrick Lenain and Sarah Fléche

1145. Deconstructing Canada's housing markets: finance, affordability and urban sprawl (July 2014) by Calista Cheung

Restructurer les marchés canadiens du logement: financements, accessibilité financière et étalement urbain (Juillet 2014) par Calista Cheung

1144. Women's role in the Swiss economy

(July 2014) by Richard Dutu

Le rôle des femmes dans l'économie suisse

(Juillet 2014) par Richard Dutu

1143. Overcoming skills shortages in Canada

(July 2014) by David Carey

Combler les pénuries de compétences au Canada

(Juillet 2014) par David Carey 
1142. Trade patterns in the 2060 world economy

(July 2014) by Jean Chateau, Lionel Fontagné, Jean Fouré, Åsa Johansson and Eduardo Olaberria

1141. The Demand for Skills 1995-2008: A global chain perspective

(July 2014) by Bart Los, Marcel P. Timmer and Gaaitzen J. De Vries

1140. International migration: The relationship with economic and policy factors in the home and destination country

(July 2014) by Ben Westmore

1139. Gross earning inequalities in OECD countries and major non-member economies: determinants and future scenarios

(July 2014) by Henrik Braconier and Jenifer Valenzuela Ruiz

1136. Long-term patterns of trade and specialisation

(July 2014) by Asa Johansson and Eduardo Olaberria

1135. Consequences of climate change damages for economic growth - a dynamic quantitative assessment

(July 2014) by Rob Dellink, Elisa Lanzi, Jean Chateau, Francesco Bosello, Ramiro Parrado and Kelly de Bruin

1134. Comparing the robustness of PAYG pension schemes

(July 2014) by Falilou Fall

1133. Overcoming vulnerabilities of pension systems

(July 2014) by Falilou Fall and Debbie Bloch

1132. Overcoming vulnerabilities of health care systems

(July 2014) by Mauro Pisu

1131. Overcoming vulnerability of unemployment insurance schemes

(July 2014) by Jon Pareliussen

1130. Vulnerability of social institutions: Lessons from the recent crisis and historical episodes

(July 2014) by Falilou Fall, Mauro Pisu, Jon Pareliussen and Debbie Bloch

1129. An update of the OECD international trade equations

(June 2014) by Myriam Morin and Cyrille Schwellnus

1128. What explains the volume and composition of trade? Industrial evidence from a panel of countries

(June 2014) by Asa Johansson, Przemyslaw Kowalski, Eduardo Olaberria and Dario Pellegrino

1127. Do resources flow to patenting firms: cross-country evidence from firm level data

(June 2014) by Dan Andrews, Chiara Criscuolo and Carlo Menon

1126. Macroprudential policy tools in Norway: Strengthening financial system resilience

(June 2014) by Yosuke Jin, Patrick Lenain and Paul O’Brien 